\title{
Determination of the Effect of Water Depth and Flow Velocity on the Quality of an In-Stream Habitat in Terms of Climate Change
}

\author{
V. Macura, ${ }^{1}$ Z. Štefunková, ${ }^{2}$ and A. Škrinár ${ }^{1}$ \\ ${ }^{1}$ Department of Land and Water Resources Management, Faculty of Civil Engineering, Slovak University of Technology in Bratislava, \\ Radlinského 11, 81368 Bratislava, Slovakia \\ ${ }^{2}$ Department of Hydraulic Engineering, Faculty of Civil Engineering, Slovak University of Technology in Bratislava, Radlinského 11, \\ 81368 Bratislava, Slovakia
}

Correspondence should be addressed to A. Škrinár; andrej.skrinar@stuba.sk

Received 2 February 2015; Revised 4 June 2015; Accepted 14 June 2015

Academic Editor: Zhongping Lai

Copyright $\odot 2016$ V. Macura et al. This is an open access article distributed under the Creative Commons Attribution License, which permits unrestricted use, distribution, and reproduction in any medium, provided the original work is properly cited.

\begin{abstract}
The study is focused on the objectification of an assessment of the quality of an in-stream habitat in mountain and piedmont streams by the decision-making Instream Flow Incremental Methodology (IFIM) due to climate change. The quality of the habitat was assessed on the basis of a bioindication, represented by ichthyofauna. Sixty-four reaches of 47 watercourses in five river basins in Slovakia, in which ichthyologic, topographic, and hydraulic measurements were performed, were evaluated. The effect of the physical characteristics of the stream channel on the quality of the in-stream habitat has been verified on a number of reference reaches in which the measurements were performed at different water levels. From the set of the data measured, an analysis aimed at determining the impact of individual characteristics on the quality of an in-stream habitat has been carried out. The results show the optimum ratio of the weights of the flow velocity and water depth for an assessment of the quality of an in-stream habitat due to climate change.
\end{abstract}

\section{Introduction}

Water management planning and decision-making should be based on the forecasting or modeling of the quality of an aquatic habitat, for example, the impact of water takeoffs, river training, river restoration, or the effects of climate change. Based on the modeling of trends in the habitat quality, data can be obtained which should characterize the impact of these changes on the aquatic ecosystem. The results of the modeling are important in the decision-making process of water management solutions. The models are mainly based on hydrological, morphological, and hydraulic parameters affecting the distribution and abundance of organisms in the stream, or in other words, the bioindication, for example, comprehensive monitoring of the aquatic environment using bioindication by macrophytes, macroinvertebrates, and fish by Friberg et al. [1]. In the last 40 years considerable efforts have been spent to develop supporting mechanisms used in determining the flow regimes necessary for protecting and improving water resources as described by Jowett [2], Hardy [3], or Tharme [4]. The results show that of all the aquatic organisms, fish react most sensitively to morphological changes.

At the beginning of our research the macrozoobenthos was studied along with the ichthyofauna. The invertebrates responded to changes in flow and hydraulic changes as discussed by Mérigoux et al. [5] or Hodkinson and Jackson [6] but were less sensitive to morphological changes in regulated mountain streams. Fish were sensitive to these changes as shown by Slavík et al. [7], and they also sensitively responded to changes in water temperature and discharges as discussed by Lamouroux et al. [8]. The sensitivity of fish caused by river regulation was also confirmed in a study of Macura et al. [9].

Different species prefer different habitats, while the age of a fish has a significant impact on its habitat preferences. 
Particular species and age groups prefer various flow velocities, depths, and types of substrate [10]. Therefore, the spatial distribution of combinations of hydraulic parameters plays an important role in the availability of a suitable in-stream habitat. Among the wide range of various models intended for the modeling of a habitat quality IFIM is the most widely used in the United States and one of the most popular models in the world [4]. A very good overview of the overall philosophy, history, and development of IFIM is given in [11]. The IFIM methodology has been gradually evolving into a tool intended for planning water management strategies. For example, variations in the individual components of an ecosystem due to climate change count among the most recent topics. A number of studies have been developed on the impact of climate change on periods of drought and minimum flows, which are essential for an aquatic habitat, such as scientific articles [12-14]. The quantification of these changes on the level of their effect on different types of bioindicators requires a detailed characterization of a whole set of factors, which is a difficult task. Such results may be very important strategically, as they allow for proposing concrete restoration measures to mitigate the effects of climate change. The study gives a particular example of modeling the quality of an in-stream habitat as a result of climate change.

\section{Materials and Methods}

2.1. Characteristics of Modeling the Quality of an Aquatic Habitat. The ecological status of a stream is influenced by many factors; the most important one is the biotope of the fauna and flora of the aquatic area. The in-stream habitat structure has a substantial impact on the organization and structure of biological communities as discussed by Maddock [15]. The aim of modeling the quality of a habitat is mainly to provide a basis for the evaluation or forecasting of biological changes, which should constitute a potential impact on the ecology that is important in the decision-making process of the management of the in-stream quality. In this study the Riverine HABitat SIMulation model (RHABSIM) [1618], which is based on the IFIM methodology, was used for modeling the habitat quality. The model was developed in order to improve the possibility of determining the rate of the influence of different ways of water use on a stream channel. It is an integrated set of one-dimensional hydraulic models and microhabitat simulation models intended for determining the quality of an aquatic habitat based on the preferences of fish for a wider range of discharges. The basic biotic characteristics are the habitat suitability curves of particular fish species.

2.2. Habitat Suitability Curves (HSCs). Habitat suitability curves (HSCs) express the preferences of different types of habitat by particular fish species. They are based on the assumption that each fish species (or other bioindicators) prefers a particular combination of abiotic environmental parameters such as flow velocity and water depth, cover places, type of bottom substrate, water temperature or quality, and the like.
The curves for flow velocity and water depth are the most widely used expressions of habitat preferences in the RHABSIM model. These curves are continuous, because the velocities and depths between all the nodes may be interpolated. Suitability curves, along with the hydraulic and topographic characteristics, allow for quantifying the quality of an aquatic habitat in the form of area weighted suitability.

2.3. Area Weighted Suitability (AWS). Area weighted suitability (AWS) is defined as the total area of the water level, which is adjusted by the suitability ratio of the individual parameters (flow velocity, water depth, cover places, etc.). This procedure is implemented by individual cells that represent microhabitats with the same characteristics. AWS shows the changes in a habitat quality with respect to the variable parameters, which are typically the discharges or changes in the morphology of the river bed. The representation of AWS by the stream length mostly has the shape of a mosaic setup of cells (Figures 6-10).

The importance of AWS has been discussed for many years. Many scientists have evaluated the correlation between AWS and a fish population or biomass, particularly in relation to the discharges, for example, Bovee [19], Conder and Annear [20], Jowett [21], Nehring and Anderson [22], and Gallagher and Gard [23], although this interpretation of a habitat quality has certain imperfections which have been highlighted by others [24-28].

When considering the representativeness of the ichthyofauna as a bioindicator, it should be noted that the term "fish" does not include only one species but is a large, morphologically, physiologically, and ecologically variable group of aquatic vertebrates living in various habitats. Ultimately, fish are the best bioindicators of morphological changes in a stream channel.

2.4. Methods. To determine the influence of various parameters on the quality of an in-stream aquatic area, the following procedure was chosen:

(i) Selection of reference reaches for a generalization of biotic characteristics.

(ii) Ichthyological sampling and a hydraulic survey aimed at a determination of the HSCs of individual fish species.

(iii) Assessment of the hydraulic characteristics of the reference reaches.

(iv) Verification of the HSCs.

(v) Determination of the AWS.

(vi) Examination of the influence of abiotic parameters on the HSCs.

(vii) Determination of the weights of the basic abiotic habitat characteristics based on the data measured.

2.5. Selection of the Reference Stream Reaches. Selection was mainly focused on smaller mountain and piedmont brooks. The reaches were selected on the basis of the structure and abundance of the ichthyofauna. The selected watercourses 
TABLE 1: Characteristics of the reference reaches in the Váh River basin.

\begin{tabular}{|c|c|c|c|c|c|c|c|c|c|c|c|c|c|}
\hline Watercourse & $\begin{array}{l}\text { Channel } \\
\text { character }\end{array}$ & $\mathrm{Rkm}$ & $\begin{array}{c}\mathrm{Q} \\
{\left[\mathrm{m}^{3} \cdot \mathrm{s}^{-1}\right]}\end{array}$ & $\begin{array}{c}\text { Drainage } \\
\text { area } \\
{\left[\mathrm{km}^{2}\right]}\end{array}$ & $\begin{array}{l}\text { Reach } \\
\text { length } \\
{[\mathrm{m}]}\end{array}$ & $\begin{array}{l}B_{p} \\
{[\mathrm{~m}]}\end{array}$ & $\begin{array}{r}h_{\max } \\
{[\mathrm{m}]}\end{array}$ & $\begin{array}{l}h_{p} \\
{[\mathrm{~m}]}\end{array}$ & $\begin{array}{c}h_{p \max } \\
{[\mathrm{m}]}\end{array}$ & $\begin{array}{c}v_{\max } \\
{\left[\mathrm{m} \cdot \mathrm{s}^{-1}\right]}\end{array}$ & $\begin{array}{c}v_{p} \\
{\left[\mathrm{~m} \cdot \mathrm{s}^{-1}\right]}\end{array}$ & $\begin{array}{c}v_{p \max } \\
{\left[\mathrm{m} \cdot \mathrm{s}^{-1}\right]}\end{array}$ & $i_{p}$ \\
\hline Drietomica & Regulated & 3.1 & 0.38 & 90.3 & 100 & 4.2 & 0.61 & 0.43 & 0.52 & 0.536 & 0.378 & 0.482 & 0.007 \\
\hline Drietomica & Natural & 5.2 & 0.38 & 82.495 & 241 & 4.8 & 0.68 & 0.46 & 0.56 & 0.724 & 0.329 & 0.463 & 0.006 \\
\hline Hradnianka & Natural & 5.7 & 0.142 & 32.143 & 124.8 & 3.4 & 0.3 & 0.11 & 0.19 & 0.764 & 0.388 & 0.547 & 0.008 \\
\hline Hybica 1 & Natural & 0.8 & 0.429 & 44.784 & 111.4 & 6.13 & 0.78 & 0.26 & 0.48 & 0.772 & 0.281 & 0.415 & 0.007 \\
\hline Hybica 2 & Regulated & 3.75 & 0.324 & 35.284 & 74.8 & 4.25 & 0.34 & 0.16 & 0.24 & 0.675 & 0.391 & 0.527 & 0.006 \\
\hline Kamečnica & Natural & 10.6 & 0.112 & 12.772 & 94.2 & 2 & 0.21 & 0.12 & 0.18 & 0.756 & 0.402 & 0.482 & 0.031 \\
\hline Klačianka & Natural & 0.18 & 0.346 & 27.17 & 96.3 & 4.19 & 0.36 & 0.15 & 0.22 & 0.912 & 0.51 & 0.706 & 0.007 \\
\hline Lesnianka 1 & Regulated & 0.8 & 0.167 & 25.26 & 50.2 & 4.23 & 0.33 & 0.13 & 0.23 & 0.765 & 0.284 & 0.329 & 0.021 \\
\hline Lesnianka 2 & Natural & 3.4 & 0.135 & 20.887 & 117.6 & 5.3 & 0.41 & 0.09 & 0.16 & 1.044 & 0.377 & 0.634 & 0.016 \\
\hline Manínsky potok & Natural & 3.7 & 0.245 & 9.588 & 95.2 & 3.97 & 0.47 & 0.15 & 0.26 & 0.791 & 0.37 & 0.552 & 0.02 \\
\hline Petrovička 1 & Natural & 3.05 & 0.08 & 64.175 & 86.2 & 5.31 & 0.11 & 0.04 & 0.08 & 0.651 & 0.312 & 0.464 & 0.022 \\
\hline Petrovička 2 & Regulated & 5.55 & 0.029 & 33.465 & 63.4 & 2.03 & 0.12 & 0.06 & 0.11 & 0.645 & 0.201 & 0.316 & 0.01 \\
\hline Teplička 1 & Regulated & 7.4 & 0.29 & 55.406 & 60 & 5.56 & 0.39 & 0.19 & 0.36 & 0.357 & 0.196 & 0.325 & 0.006 \\
\hline Teplička 2 & Natural & 10.2 & 0.283 & 51.081 & 69.4 & 5.14 & 0.8 & 0.2 & 0.34 & 0.926 & 0.31 & 0.441 & 0.022 \\
\hline Veselianka 1 & Natural & 3.76 & 1.225 & 85.869 & 143.1 & 11.36 & 0.62 & 0.27 & 0.45 & 0.898 & 0.384 & 0.566 & 0.01 \\
\hline Veselianka 2 & Natural & 7.6 & 0.905 & 69.116 & 98.6 & 12.93 & 0.68 & 0.24 & 0.45 & 0.481 & 0.247 & 0.379 & 0.011 \\
\hline Vrzavka & Natural & 4.8 & 0.09 & 10 & 78.8 & 3.36 & 0.14 & 0.06 & 0.11 & 0.844 & 0.363 & 0.553 & 0.015 \\
\hline Vôdky & Natural & 2.1 & 0.221 & 15.792 & 167 & 3.02 & 0.22 & 0.13 & 0.2 & 0.736 & 0.47 & 0.649 & 0.018 \\
\hline Zázrivka 1 & Natural & 7.9 & 1.025 & 76.473 & 100.7 & 13.57 & 0.61 & 0.2 & 0.39 & 0.994 & 0.353 & 0.545 & 0.014 \\
\hline Zázrivka 2 & Natural & 0.3 & 1.441 & 96.094 & 98.6 & 13.21 & 0.48 & 0.22 & 0.37 & 0.764 & 0.416 & 0.607 & 0.012 \\
\hline Vadičovský potok & Natural & 1.1 & 0.223 & 39.39 & 103.5 & 4.32 & 0.25 & 0.1 & 0.17 & 0.821 & 0.458 & 0.675 & 0.017 \\
\hline
\end{tabular}

of all the river basins are shown in Figure 1 with the main characteristics of the reference reaches in the Váh River basin given in Table 1. Besides Váh, watercourses belonging to four other river basins were evaluated: Dunajec and Poprad basin, Nitra basin, Bodrog basin, and Hron basin. These are not listed in detail.

2.6. Ichthyological Sampling and Hydraulic Survey. The ichthyologic measurements were aimed at determining the HSCs of the individual fish species. The ichthyological sampling as well as the topographic measurements was carried out during the summer months due to the need to monitor the conditions of the in-stream habitats during minimum flows. The ichthyological data were collected by the HansGrassl ELT62II-HI electrofishing device. The flow velocities, water depths, and character of the microhabitat (type of cover and bottom substrate) were recorded at all the points of the fish capture. The flow velocities were measured by hydrometric propellers, and the topography of the riverbed was measured by the Leica Flexline TS02 total station with an angle accuracy of $3^{\prime \prime}$.

2.7. Hydraulic Characteristics of the Selected Stream Reaches. The hydraulics of a river channel determine the quality of a habitat suitable for ichthyofauna. Habitat suitability curves for the flow velocity and water depths represent a biotic component of the method. The peaks of the curves were compared, that is, spots with the highest occurrence of the species in particular depths at certain velocities, which are referred to as the velocity parameter $\left(P_{v}\right)$ and the depth parameter $\left(P_{d}\right)$.

The Pearson product-moment correlation coefficient $(r)$ was used for the measurement of the correlation relationship between the parameters mentioned. Cohen [29] states out the evaluation of Pearson's $r$ as follows: no correlation: 0.0 to 0.09 ( -0.09 to 0.0$)$, small degree of correlation: 0.1 to 0.3 ( -0.3 to -0.1$)$, medium degree of correlation: 0.3 to 0.5 $(-0.5$ to -0.3$)$, and large degree of correlation: 0.5 to $1.0(-1.0$ to -0.5$)$. The regulated and natural reaches of the streams were distinguished for the purposes of the statistical analysis. The database was divided into three files: a file of regulated reaches, a file of natural streams, and a file of all the reaches created by the union of natural and regulated stream reaches.

Correlation relationships were determined between the parameters of $P_{v}$ and $P_{d}$ with the slope of the energy line $(i)$ and the $M$-constant $(M)$, which is equivalent to the Chézy coefficient $(C)$. The $M$-constant depends on the discharges and heights of the water levels, similar to the Chézy coefficient. A more detailed description of the $M$-constant is given in the literature [30].

The $M$-constant was calculated from K. V. Grišanin's equation:

$$
M=\frac{R(g \cdot B)^{1 / 4}}{Q^{1 / 2}},
$$




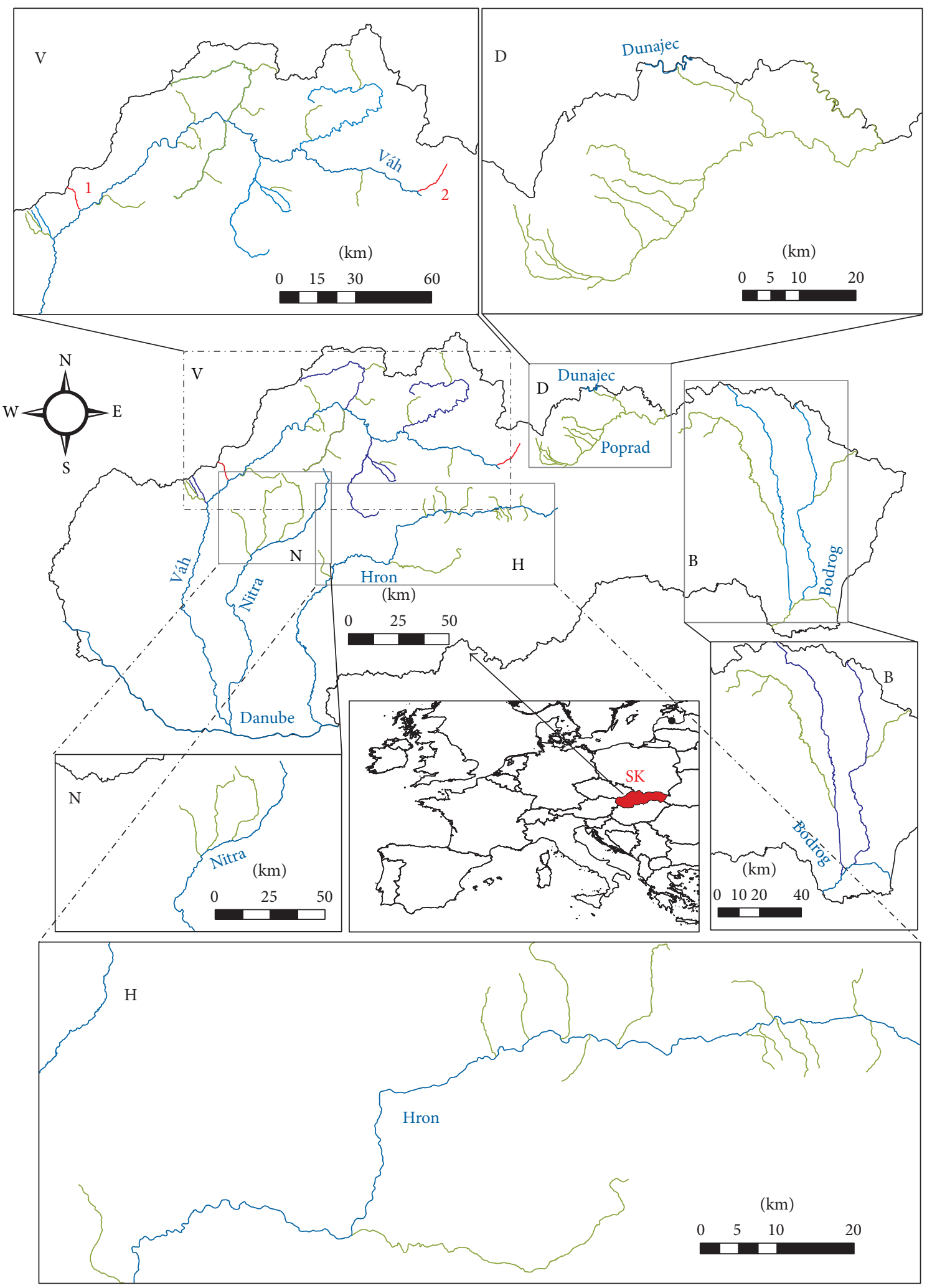

Figure 1: Map of the selected watercourses (SK: Slovak Republic, V: Váh basin, D: Dunajec and Poprad basin, N: Nitra basin, B: Bodrog basin, $\mathrm{H}$ : Hron basin, 1: Drietomica, and 2: Hybica; the blue lines indicate rivers; the green lines indicate the selected watercourses). 
TABle 2: Comparison of the Pearson correlation coefficient $(r)$ for the brown trout between the following variables: velocity parameter $\left(P_{v}\right)$, depth parameter $\left(P_{d}\right)$, the $M$-factor $(M)$, and hydraulic slope of the energy line $(i)$.

\begin{tabular}{lcccc}
\hline Set of watercourses & $P_{v}-M$ & $P_{d}-M$ & $P_{v}-i$ & $P_{d}-i$ \\
\hline (1) All the watercourses & 0.06 & 0.14 & -0.24 & -0.14 \\
(2) Regulated channels & $\mathbf{0 . 6 4}$ & -0.28 & -0.33 & 0.15 \\
(3) Natural channels & 0.13 & $\mathbf{0 . 5 2}$ & -0.17 & -0.30 \\
\hline
\end{tabular}

where $g$ is the acceleration of gravity $\left[\mathrm{m} \cdot \mathrm{s}^{-2}\right], B$ is the channel width at the water level $[\mathrm{m}], R$ is the hydraulic radius $[\mathrm{m}]$, and $Q$ is the discharge $\left[\mathrm{m}^{3} \cdot \mathrm{s}^{-1}\right]$.

From the statistical assessment (Table 2), it follows that

(i) a strong correlation in the relationship of $P_{v}-M(r=$ $0.64)$ was shown in the regulated streams. On the contrary, the correlation relationship of $P_{d}-M$ was small $(r=-0.28)$. The reason for this result is that the regulated streams have prismatic channels with a small range of water depths. Therefore, the fish, especially brown trout (Salmo trutta m. fario), prefer biotopes based on flow velocity,

(ii) the opposite effect occurred in natural channels, since there was a degree of correlation demonstrated in the relationship of $P_{d}-M$ as large $(r=0.52)$ and the correlation in the relationship of $P_{v}-M$ as small (0.13). This result is directly related to the morphological characteristics of a natural stream channel. Trout prefer cover places with sufficient depths. Flow velocity is not crucial in reaches with larger depths, because there are generally low velocities in these spots (cover places).

(iii) In the set of all the watercourses (regulated and natural) no correlation has been proved.

The results shown in Table 2 directly confirmed the sensitivity of the trout as a bioindicator for habitat parameters that are dominant at characteristic reaches. An important fact is that there was a relationship between the morphological parameters of the channel and the microhabitat preference by brown trout as a bioindicator of environmental quality.

2.8. Influence of Abiotic Parameters on the HSCs. The aim of our further research was to determine whether there is a correlation between the shape of the HSCs and the abiotic parameters of in-stream habitats. Data from the database of the field measurements at the watercourses listed in Table 1 were used for the analysis. Only those streams where brown trout occurred in such numbers that it was possible to reliably determine the suitability curves for the depths were evaluated. The results were verified using the data of the Drietomica brook. Comprehensive field measurements were carried out for three different water levels.

The depth parameters (dependent variable) were correlated with the average maximum depths (independent variable). The average maximum depths were determined by averaging the maximum depth at each cross section of the

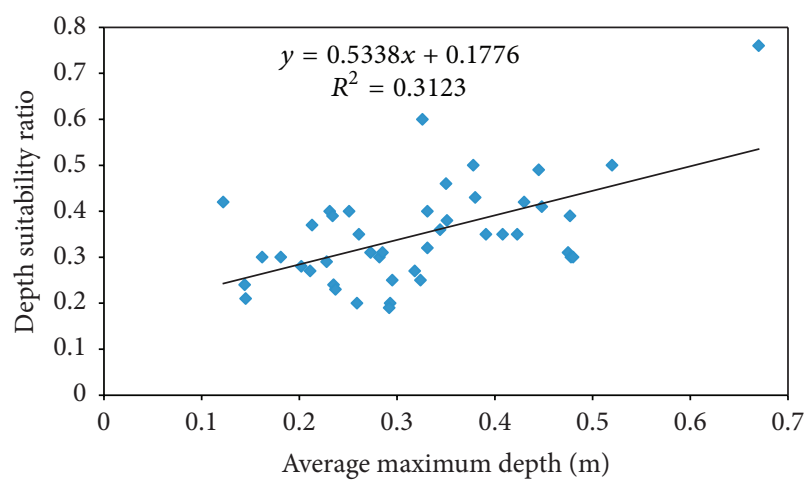

FIgure 2: Correlation between the mean maximum depths and depth parameters for the brown trout.

selected reach. Graph of the correlation between the mean maximum depths and the depth parameters for the brown trout is shown in Figure 2.

The correlation coefficient evaluated from all the watercourses has a value of 0.55 , which indicates a large degree of dependence. Since there are also regulated reaches in the database, the correlation coefficient was evaluated separately for the reaches with a natural character. In this case, $r$ took the value of 0.67 , which was close to a very high degree of dependence. From the results it can be concluded that the shape of the HSCs is greatly influenced by the average maximum depths of a channel.

2.9. Verification of the HSCs Using the Example of the Drietomica Brook. The Drietomica brook was selected to be the verification reach since it is a mountain stream with a variable morphology and has a minimum impact from human activities. In the years 2004-2013, a detailed field survey was carried out, which focused on a comprehensive evaluation of the quality of the aquatic habitat by the RHABSIM model. A set of topographical, hydrometrical, and ichthyological measurements aimed at evaluating the quality of the in-stream habitat of various types of fish covers was realized. These data formed the basis of a detailed analysis of the reference reach at the Drietomica brook with the aim of optimizing the ratio of $W_{V}: W_{D}$. Three various discharges along with the water-level regimes were measured: $Q_{1}=0.55 \mathrm{~m}^{3} \cdot \mathrm{s}^{-1}$, corresponding to the discharge of $Q_{180 d}$, $Q_{2}=1.48 \mathrm{~m}^{3} \cdot \mathrm{s}^{-1}$, corresponding to the discharge of $Q_{60 d}$, and $Q_{3}=0.08 \mathrm{~m}^{3} \cdot \mathrm{s}^{-1}$, representing the discharge of $Q_{365 d}$. For each discharge ichthyological sampling was performed that focused on the habitat preferences by the ichthyofauna to derive the HSCs. From the measurements for the three various water levels, the HSCs for the brown trout (Figures 3 and 4) were determined.

The HSCs for the water depths in Figure 3 and the flow velocities in Figure 4 show that the changes in habitat preferences indicated the same trends as the changes in the water level. Specifically, during a discharge of $Q=0.085 \mathrm{~m}^{3} \cdot \mathrm{s}^{-1}$, the water depths in cover places varied from $0.15 \mathrm{~m}$ to $0.60 \mathrm{~m}$, while during the highest measured discharge of $Q=$ 


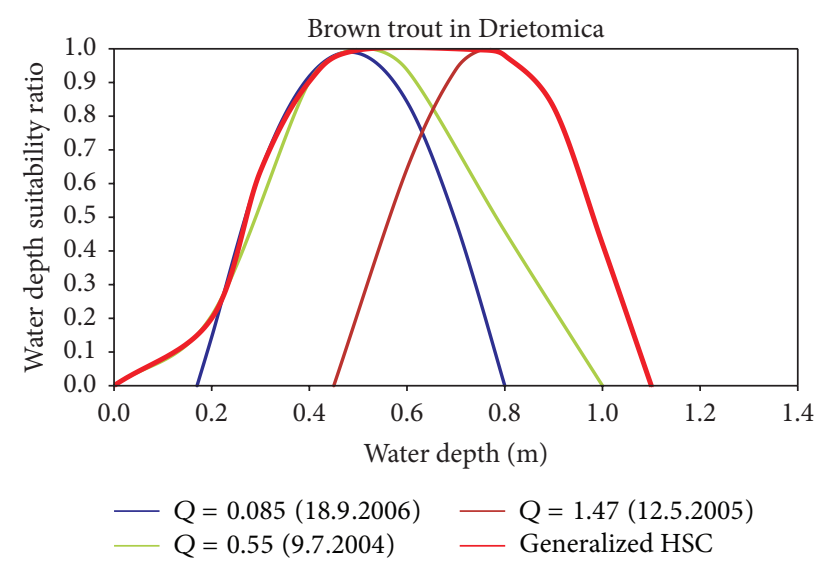

FIGURE 3: Suitability curves of the brown trout for the water depths during three various discharges and the resulting generalized suitability curve.

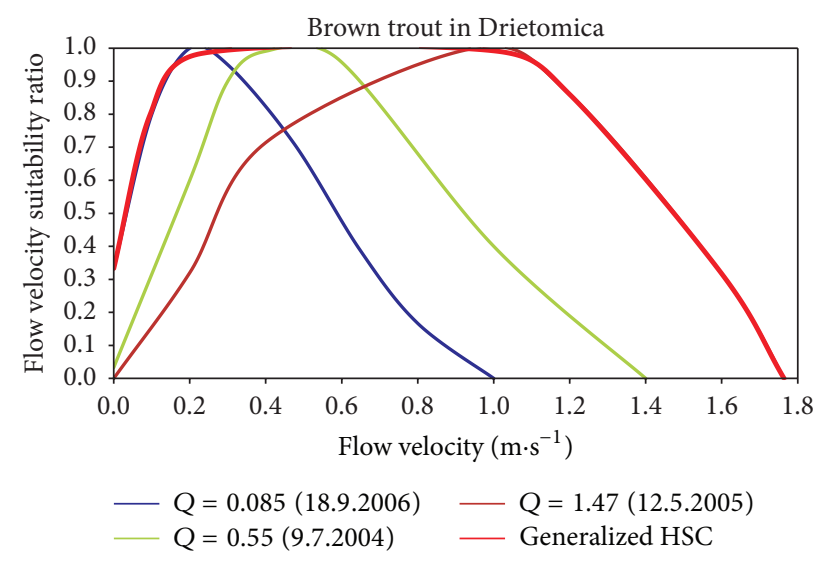

FIgURE 4: Suitability curves of the brown trout for the flow velocities during three various discharges and the resulting generalized suitability curve.

$1.47 \mathrm{~m}^{3} \cdot \mathrm{s}^{-1}$ they varied from $0.45 \mathrm{~m}$ to $0.85 \mathrm{~m}$. Thus, the difference in the $P_{D}$ was $25 \mathrm{~cm}$. Changes in the water levels during the above discharges varied from 0.2 to $0.3 \mathrm{~m}$ in particular cross sections. Hence, the changes in the water levels were similar to the changes in the $P_{D}$. We obtained similar results by comparing the changes in the $P_{V}$ and the maximum flow velocities. The above analysis leads us to a conclusion that in habitats with acceptable velocities: fish do not change their cover places (an acceptable flow velocity is one that does not prevent the fish specimen from the long-term use of a microhabitat). In other words, with an increasing discharge a certain fish specimen prefers the same microhabitat until it is forced to switch to another cover (current shadow) by high velocities.

2.10. Evaluation of the AWS. The AWS is the result of a simulation process in the RHABSIM model. Based on the hydraulic parameters, an index from the HSCs of individual species (separately for the flow velocities and water depths, or other factors) is assigned to each individual microhabitat cell at the reference reach. The so-called combined suitability factor (CSF) is calculated by multiplying the flow velocity and water depth suitability values:

$$
\mathrm{CSF}=V \cdot D \cdot A,
$$

where $V$ is the velocity suitability value, $D$ is the depth suitability value, and $A$ is the suitability value for additional habitat attributes (cover, bottom substrate, etc.).

This method considers each variable to have the same weight. From the preceding text it follows that the water depth affects the quality of the habitat more significantly than the flow velocity and that it is similar with different types of fish covers. It is necessary to consider the different weights for each parameter. Therefore, we recommend the CSF to be evaluated according to

$$
\operatorname{CSF}=\frac{\left(V \cdot W_{V}\right)+\left(D \cdot W_{D}\right)+\left(A \cdot W_{A}\right)}{\left(W_{V}+W_{D}+W_{A}\right)},
$$

where $W_{V}$ is the weighting factor for flow velocity, $W_{D}$ is the weighting factor for water depth, and $W_{A}$ is the weighting factor for additional attribute (any weight from 0.1 to 1.0 can be assigned to each factor). The AWS is then determined by multiplying the water surface of the particular cells and their CSF:

$$
\mathrm{AWS}=S_{b} \cdot \mathrm{CSF}
$$

where $S_{b}$ is the area of the water surface of the cells $\left[\mathrm{m}^{2}\right]$ and CSF is the combined suitability factor.

The total of the area weighted suitability is determined by the sum of the partial AWSs. RHABSIM allows for a representation of habitat suitability for individual cross sections for each water level and fish species, as well as a situational projection of the suitability ratio in the context of the surface area in the individual cells.

The AWS was investigated by changing the weights of the flow velocity and water depth suitability values. The effect of this balance was analyzed according to (3) and its modification having the form

$$
\mathrm{CSF}=\left(V^{W_{V}} \cdot D^{W_{D}} \cdot A^{W_{A}}\right)
$$

Provided that all of the weights are nonnegative, the following may be stated:

$$
W_{V}+W_{D}+W_{A}=1 .
$$

The third additional attribute $(A)$ and its weight $\left(W_{A}\right)$ may represent a type of cover or substrate. The velocity fields at the selected reaches were verified at the water levels, which were measured during the ichthyological survey. The biotic area was represented by normalized HSCs.

Comparison of the results evaluated in accordance with (3) and (5) showed minimum differences. We used the CSF evaluation by (3). In the text below the calculation of the AWS according to (2) is referred to as Method 1 , and the calculation of the AWS according to (3) is referred to as Method 2.

From the AWS values modeled by Method 1, it follows that the results do not match the actual status of the habitat. 
When combining a suitable parameter (water depth) and a less suitable parameter (flow velocity), the total AWS of this method is unsuitable, or the suitability is low. It is necessary to recall that the RHABSIM model does not provide other options. Therefore, we have created our own AWS assessment procedure for the application of Method 2.

As mentioned above, the water depth has a significantly greater effect on the quality of the habitat than it does on velocity. Correct determination of the weights of these parameters is an essential step towards the objectification of the AWS according to Method 2.

Optimum ratio of $W_{D}: W_{V}$ was derived from the five reference reaches in three streams (Slatina, Drietomica, and Udava). The reference reaches were subdivided into particular microhabitats that have been identified and marked in the field. During the ichthyologic survey the water depths and flow velocities were measured at the sites of the catch of each fish and have been associated with a specific microhabitat. These data were compared to the results from the RHABSIM model at different ratios of weights. A comparison of the suitability values and number of fish caught showed the best match at a ratio of $W_{D}: W_{V}=8: 2$.

The AWS was evaluated by the two methods mentioned above: Method 1 according to (2) and Method 2 according to (3) (ratio $W_{D}: W_{V}=8: 2$ ). The HSCs for the entire range of discharges for depth and velocity shown in Figures 3 and 4 by the red line were used for the evaluation of the habitat quality. Typical riffle and pool habitats were selected to determine the AWS. Table 3 indicates the percentage differences of the AWS evaluated by Methods 1 and 2 with the ratio of the weights $W_{D}: W_{V}=8: 2$. For the calculation of the difference, the following relationship was used:

$$
\Delta=\frac{\mathrm{AWS}_{\text {met.2 }}-\mathrm{AWS}_{\text {met.1 }}}{\mathrm{AWS}_{\text {met.2 }}} \cdot 100,
$$

where $\Delta$ is the percentage difference of the AWS by Methods

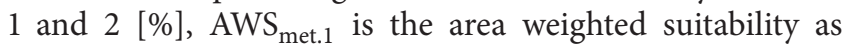
determined by Method $1\left[\mathrm{~m}^{2} / \mathrm{m}\right]$, and AWS $\mathrm{met} .2_{2}$ is the area weighted suitability as determined by Method $2\left[\mathrm{~m}^{2} / \mathrm{m}\right]$.

Differences in the resulting AWSs are given in Table 3, wherein the average difference was $31.6 \%$ in the riffle habitats. Reaches with pool habitats were evaluated by the same method with differences of $12.9 \%$. The results have indicated that there is a significant difference between the methods used. Comparison of the AWS by Methods 1 and 2 for all the cross sections of the Drietomica brook is shown in Figure 5.

\section{Discussion}

Despite the uncertainty in future trends of climate and land use change and in species responses to these interacting drivers, it is important to attempt to understand these effects; otherwise current conservation practice may become ineffective. Inappropriate habitat management could exacerbate biodiversity declines [31]. Petts [32] notes that the expert judgment is always important regardless of the tool and the method used for determining the minimum flow. From a water management point of view, it is important to characterize the shape of the HSCs in the range of minimum flows. The effect of the discharge and the shape of the HSCs on the habitat quality were analyzed at the reference reach of the Drietomica brook. The first stage was to evaluate the quality of the habitat for the discharge of $Q=0.085 \mathrm{~m}^{3} \cdot \mathrm{s}^{-1}$ and $Q=$ $1.48 \mathrm{~m}^{3} \cdot \mathrm{s}^{-1}$ using the HSCs derived from the same discharge. A comparison of the results in Figures 6 and 7 shows that the habitat quality for the velocity parameter was very good for both discharges, but concerning the depth parameter, the habitat quality paradoxically decreases when the water depths increase. However, when we used the $Q=0.085 \mathrm{~m}^{3} \cdot \mathrm{s}^{-1}$ curve for the $Q=1.48 \mathrm{~m}^{3} \cdot \mathrm{s}^{-1}$ discharge, the habitat quality for the depth parameter was logically increasing, but on the contrary it was decreasing for the velocity parameter (Figure 8). The same trend in both parameters was also confirmed for a discharge of $Q=2.235 \mathrm{~m}^{3} \cdot \mathrm{s}^{-1}$ (Figures 9 and 10).

The above results provide a logical explanation: in a period of minimum flows fish prefer cover places with maximum depths. During a slight increase in a discharge, the fish remains in the same habitat. This means that for a fish caught at the same location, the higher depth is recorded; therefore, the preferred depth increases with an increase in the discharge; this trend is also confirmed in Figure 3. From these results it can be stated that the HSCs should be derived for the minimum flows, and the peak of the curve should be shifted to an area where the fish is forced to find another cover place because of the higher velocities. These curves are shown in Figures 3 and 4 marked with a red line. The ideal situation would be to have a set of measurements from the minimum flow to the discharge when the habitat preference of the fish is changed based on the velocities. Hence, the rising part of the curve would be derived at the minimum flow conditions, while the descending part should be derived at the conditions which lead to relocations of a fish population. The determination of such a discharge would be extremely difficult for a number of reasons. In our case, the discharge of $Q=1.48 \mathrm{~m}^{3} \cdot \mathrm{s}^{-1}$ was used for the descending part of the curve (Figure 3 ).

The quality of the habitat determined by such a modified HSC has a logical development. That is, for the depth parameter the quality of the habitat increases with an increasing discharge. The quality of the habitat for the velocity parameter has a similar development. This means that there were no observed relocations of the fish population during $Q=$ $1.48 \mathrm{~m}^{3} \cdot \mathrm{s}^{-1}$. Also, in this case it may be stated that the trout preferred a habitat according to the water depths and that the impact of the flow velocities on the quality of the habitat was indirect. In terms of the flow velocity there are two limiting factors. During the small velocities (the rising part of the HSC), it is a change in the quality of the riverbed material. During the low velocities sedimentation processes occur. The natural sand-gravel substrate is covered by a fine material, which has a negative impact on the quality of the habitat (during flow velocities lower than $0.1 \mathrm{~m} \cdot \mathrm{s}^{-1}$ in a modified HSC). The flow velocities that maintain the natural character of the riverbed are suitable in the microhabitat. During higher velocities (descending part of the HSC), the limiting factor is the ability of fish to withstand the streamflow up to the 
TABLE 3: Percentage difference of the AWS evaluated by Methods 1 and 2 with the ratio of weights $W_{D}: W_{V}=8: 2$.

\begin{tabular}{|c|c|c|c|c|c|c|}
\hline \multirow[b]{2}{*}{ Cross section number } & \multicolumn{3}{|c|}{ Riffles } & \multicolumn{3}{|c|}{ Pools with greater depths } \\
\hline & $\begin{array}{c}\text { AWS met.1 } \\
{\left[\mathrm{m}^{2} / \mathrm{m}\right]}\end{array}$ & $\begin{array}{c}\text { AWS met.2 } \\
{\left[\mathrm{m}^{2} / \mathrm{m}\right]}\end{array}$ & $\begin{array}{c}\Delta \\
{[\%]}\end{array}$ & $\begin{array}{c}\text { AWS met.1 } \\
{\left[\mathrm{m}^{2} / \mathrm{m}\right]}\end{array}$ & $\begin{array}{c}\text { AWS met.2 } \\
{\left[\mathrm{m}^{2} / \mathrm{m}\right]}\end{array}$ & $\begin{array}{c}\Delta \\
{[\%]}\end{array}$ \\
\hline 3 & & & & 0.53 & 0.82 & 35 \\
\hline 4 & & & & 1.42 & 2.01 & 29.4 \\
\hline 5 & & & & 3.33 & 4.69 & 29 \\
\hline 6 & & & & 2.75 & 5.17 & 46.8 \\
\hline 13 & 1.39 & 2.93 & 52.5 & & & \\
\hline 14 & 13.28 & 22.02 & 39.7 & & & \\
\hline 15 & 13.68 & 31.72 & 56.9 & & & \\
\hline 20 & & & & 27.67 & 29.09 & 4.9 \\
\hline 21 & & & & 9.7 & 10.56 & 8.1 \\
\hline 22 & & & & 9.75 & 10.48 & 7 \\
\hline 23 & & & & 12.54 & 13.13 & 4.5 \\
\hline 24 & & & & 14.04 & 14.51 & 3.3 \\
\hline 28 & & & & 4.18 & 4.56 & 8.3 \\
\hline 29 & & & & 7.15 & 7.91 & 9.6 \\
\hline 30 & 17.78 & 21.81 & 18.5 & & & \\
\hline 31 & 20.9 & 24.88 & 16 & & & \\
\hline 32 & & & & 8.5 & 10.05 & 15.4 \\
\hline 33 & & & & 4.63 & 5.09 & 9 \\
\hline 34 & & & & 1.78 & 1.92 & 7.2 \\
\hline 35 & & & & 6.71 & 7.3 & 8.1 \\
\hline 36 & & & & 9.44 & 10.82 & 12.8 \\
\hline 37 & & & & 7.96 & 8.58 & 7.2 \\
\hline 38 & & & & 3.71 & 4.01 & 7.5 \\
\hline 39 & & & & 4.8 & 5.15 & 6.8 \\
\hline 40 & & & & 4.84 & 5.18 & 6.6 \\
\hline 41 & & & & 2.18 & 2.34 & 6.9 \\
\hline 42 & & & & 12.44 & 13.07 & 4.9 \\
\hline 43 & & & & 10.75 & 11.69 & 8 \\
\hline 44 & & & & 4.62 & 5.07 & 8.9 \\
\hline 47 & 10.33 & 13.61 & 24.1 & & & \\
\hline 48 & 14.73 & 19.41 & 24.1 & & & \\
\hline 49 & 9.02 & 12.34 & 26.9 & & & \\
\hline 50 & & & & 2.18 & 2.77 & 21.4 \\
\hline 51 & 2.02 & 2.61 & 22.6 & & & \\
\hline 52 & 2.91 & 4.27 & 31.8 & & & \\
\hline 53 & 2.68 & 4.06 & 33.9 & & & \\
\hline 54 & 4.13 & 5.6 & 26.3 & & & \\
\hline 55 & & & & 6.9 & 7.71 & 10.5 \\
\hline 56 & 9.97 & 13.5 & 26.2 & & & \\
\hline 57 & 18.71 & 23.72 & 21.1 & & & \\
\hline 58 & 11.74 & 14.21 & 17.4 & & & \\
\hline 59 & 1.41 & 1.87 & 24.6 & & & \\
\hline 60 & 7.69 & 10.96 & 29.8 & & & \\
\hline 61 & 10.66 & 16.66 & 36 & & & \\
\hline 62 & 4.47 & 9.15 & 51.1 & & & \\
\hline 63 & 1.6 & 2.7 & 40.8 & & & \\
\hline 64 & 3.08 & 4.38 & 29.7 & & & \\
\hline 65 & 0.32 & 1.33 & 76 & & & \\
\hline 67 & & & & 3.41 & 4.62 & 26.2 \\
\hline
\end{tabular}


TABLE 3: Continued.

\begin{tabular}{|c|c|c|c|c|c|c|}
\hline \multirow[b]{2}{*}{ Cross section number } & \multicolumn{3}{|c|}{ Riffles } & \multicolumn{3}{|c|}{ Pools with greater depths } \\
\hline & $\begin{array}{c}\text { AWS met.1 } \\
{\left[\mathrm{m}^{2} / \mathrm{m}\right]}\end{array}$ & $\begin{array}{c}\text { AWS met.2 } \\
{\left[\mathrm{m}^{2} / \mathrm{m}\right]}\end{array}$ & $\begin{array}{c}\Delta \\
{[\%]}\end{array}$ & $\begin{array}{c}\text { AWS met.1 } \\
{\left[\mathrm{m}^{2} / \mathrm{m}\right]}\end{array}$ & $\begin{array}{c}\text { AWS met.2 } \\
{\left[\mathrm{m}^{2} / \mathrm{m}\right]}\end{array}$ & $\begin{array}{c}\Delta \\
{[\%]}\end{array}$ \\
\hline 68 & & & & 3.96 & 4.59 & 13.7 \\
\hline 70 & & & & 5.56 & 6.25 & 11 \\
\hline 71 & & & & 4.59 & 5.2 & 11.7 \\
\hline 72 & & & & 11.44 & 12.65 & 9.6 \\
\hline 74 & 9.49 & 12.39 & 23.4 & & & \\
\hline 75 & 2.84 & 3.42 & 17 & & & \\
\hline 76 & 2.28 & 2.84 & 19.7 & & & \\
\hline 77 & 0.97 & 1.49 & 35 & & & \\
\hline 78 & 1.22 & 1.65 & 26.1 & & & \\
\hline 79 & 1.43 & 1.96 & 27 & & & \\
\hline 80 & 4.84 & 7.34 & 34.1 & & & \\
\hline 81 & 3.2 & 5.29 & 39.5 & & & \\
\hline Average & 31.6 & 12.9 & & & & \\
\hline
\end{tabular}

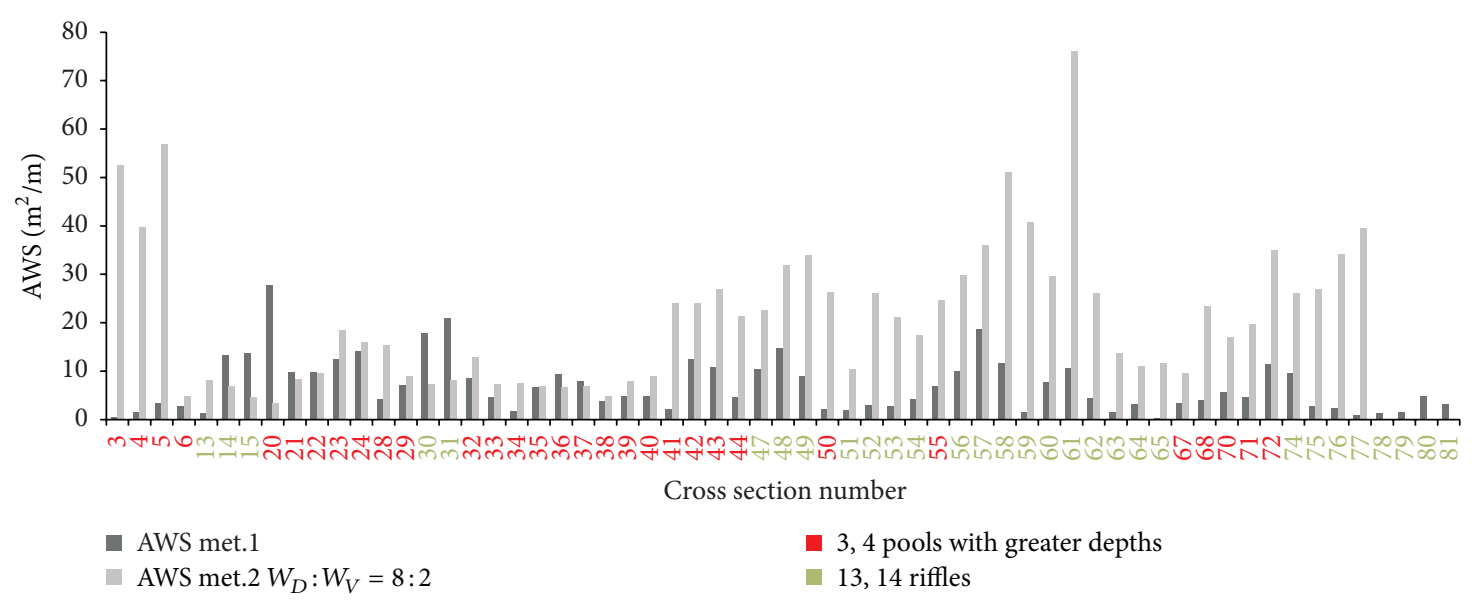

FIgURE 5: Comparison of the AWSs computed by Methods 1 and 2 (weights ratio $W_{D}: W_{V}=8: 2$ ) for the particular cross sections at the Drietomica reach.

values where the fish are forced to leave their positions for the high flow velocities and find a cover place in the current shadow. It is necessary to note that, for the purposes of water management, the rising part of the curve is crucial, as it characterizes the quality of the habitat under the maximum stress of the biota. Although the fish are forced to switch their habitat due to higher flow velocities, there are sufficient cover opportunities that create favorable conditions in the natural flow. Therefore, the descending part of the curve has no significant impact on the habitat evaluation. It has been reported that flood conditions have no significant negative impact on fish populations.

In addition to the evaluation of a simple case of changes in the quality of an aquatic habitat due to discharge variations, it is possible to solve a much more difficult task, the impact of climate change on the quality of an aquatic habitat. Addressing this issue will be documented further by a case study on the specific reach.

\section{Case Study: Modeling the Quality of an In-Stream Habitat under the Influence of Climate Change on the Hybica River}

The impact of climate change on the particular components of an ecosystem belongs among hot topics. Various studies of the impact of climate change demonstrate an increase in weather extremes that have an impact on human health (increasing mortality, illness from extreme weather) and the availability of food, water, and energy supplies [33]. One of the most determinative changes in weather extremes that we can expect is a protraction of drought seasons and the more frequent occurrence of minimum flows. Many scientific studies have paid attention to this topic, including [12-14]. Reducing discharges and a protraction of drought seasons may also have an impact on the quality of an aquatic habitat. This topic has not often been discussed [26, 34, 35]. Therefore, 

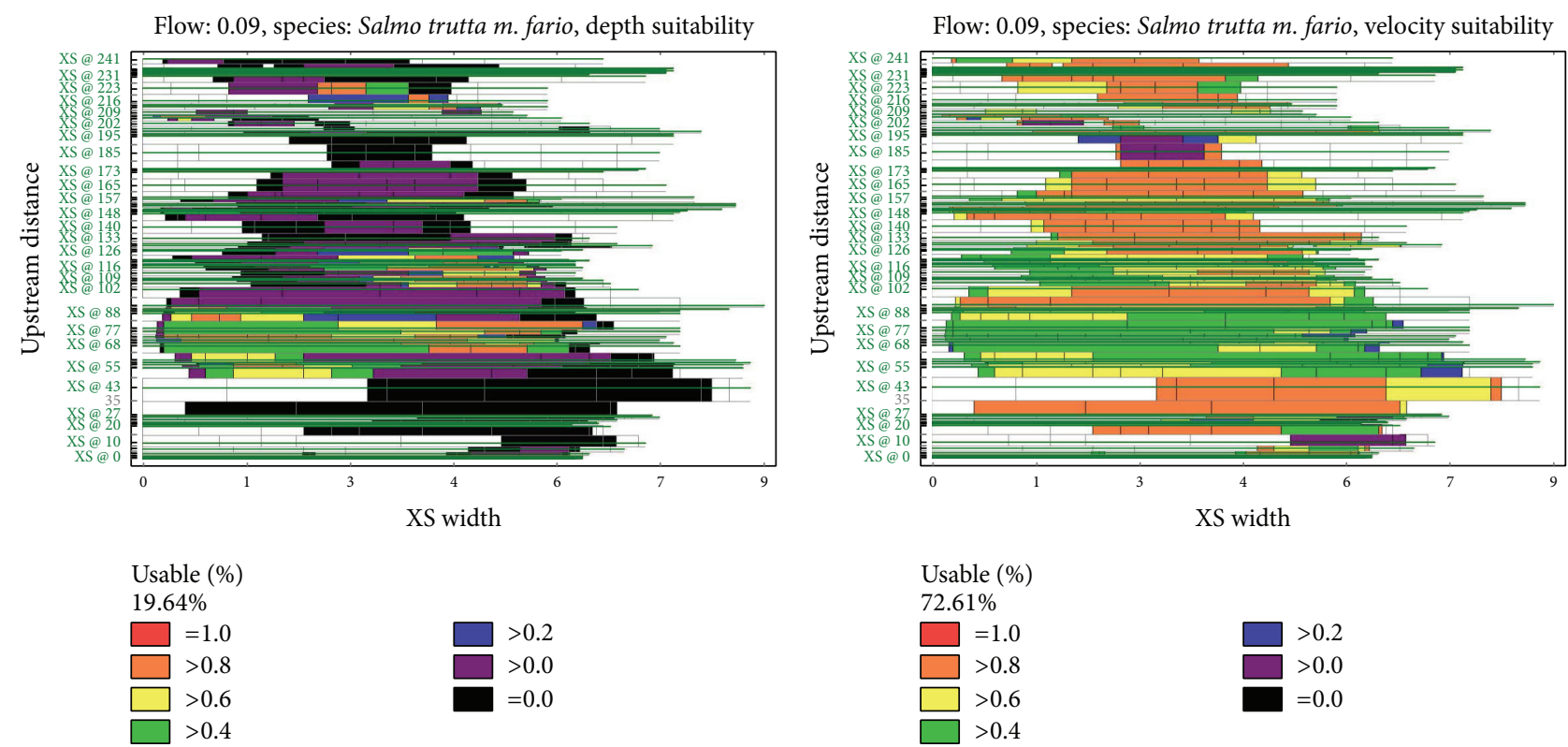

(a)

(b)

FIGURE 6: AWS during the discharge of $Q=0.085 \mathrm{~m}^{3} \cdot \mathrm{s}^{-1}$ using the HSCs evaluated during the discharge of $Q=0.085 \mathrm{~m}^{3} \cdot \mathrm{s}^{-1}$. (a) Water depth suitability, (b) flow velocity suitability. Habitat quality is scaled; black color represents an unsuitable habitat, while the red color represents the most suitable habitat.

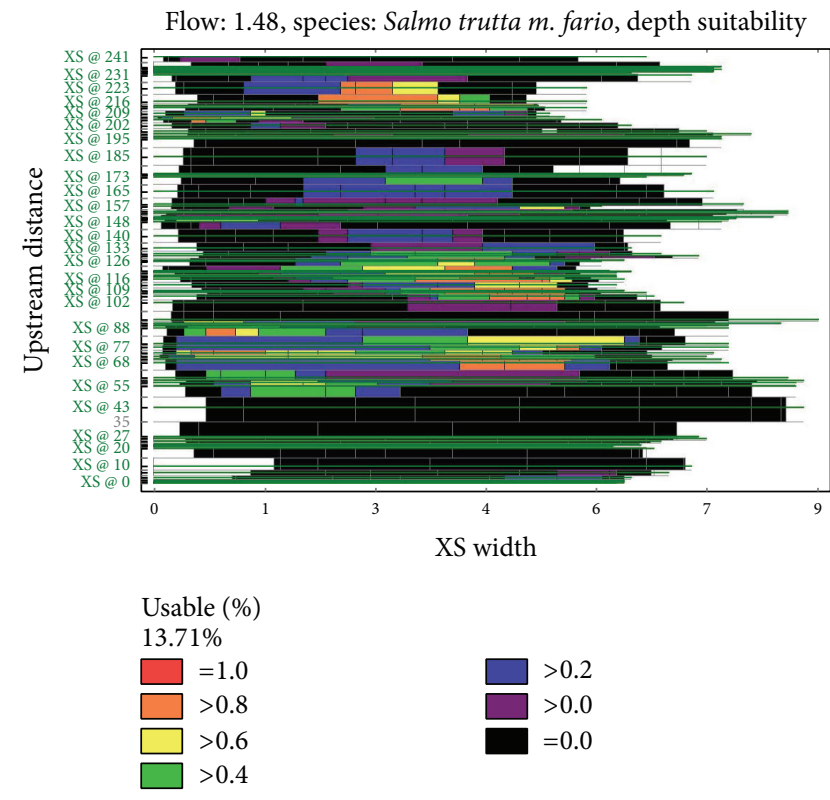

(a)

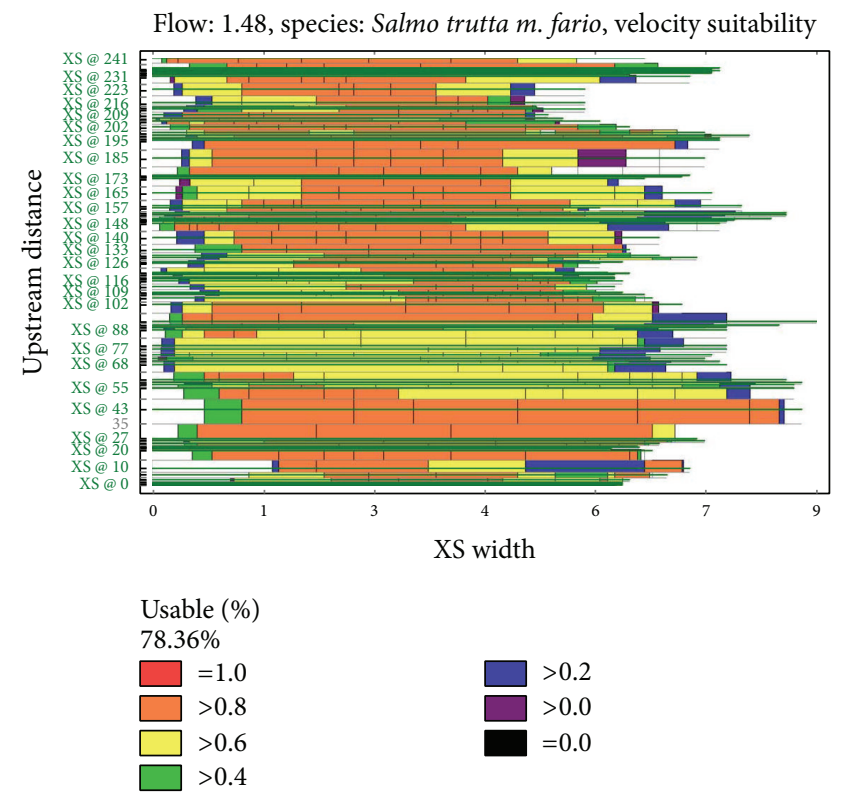

(b)

FIGURE 7: AWS during the discharge of $Q=1.48 \mathrm{~m}^{3} \cdot \mathrm{s}^{-1}$ using the HSCs evaluated during the discharge of $Q=1.48 \mathrm{~m}^{3} \cdot \mathrm{s}^{-1}$. (a) Water depth suitability, (b) flow velocity suitability.

this issue will be documented in this study at the specific reach.

The methodology for solving this issue has been divided into three areas. The first one was the calibration and validation of the Hron [36] and WetSpa [37] rainfall-runoff models, processing the outputs from the ALADIN-Climate [38], KNMI and MPI [39] climate models, and a simulation of the altered minimum flows. The second area was focused on the measurement of abiotic and biotic characteristics and modeling in-stream habitat quality. In the study this method 

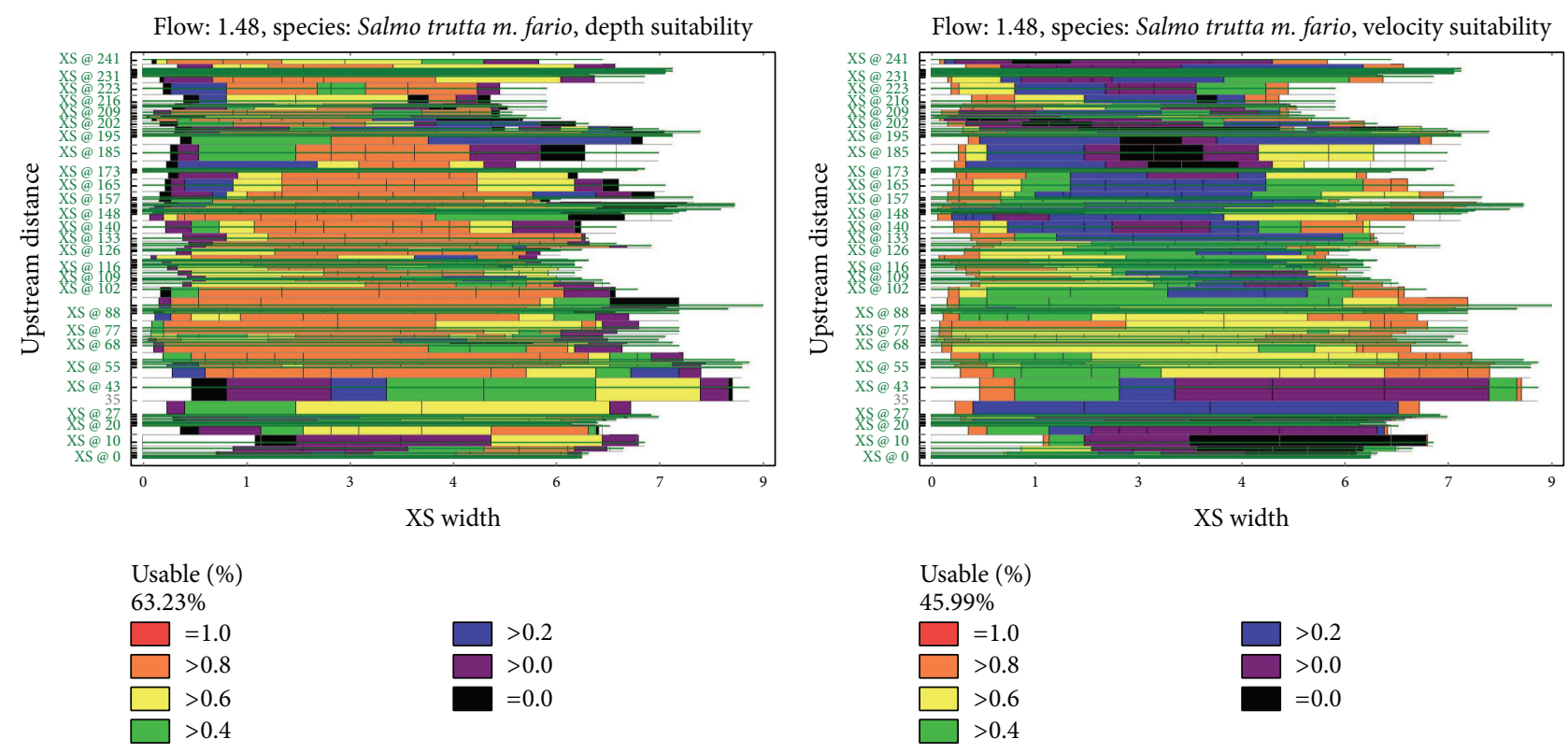

(a)

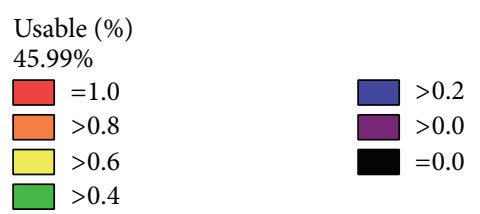

(b)

FIGURE 8: AWS during the discharge of $Q=1.48 \mathrm{~m}^{3} \cdot \mathrm{s}^{-1}$ using the HSCs evaluated during the discharge of $Q=0.085 \mathrm{~m}^{3} \cdot \mathrm{s}^{-1}$. (a) Water depth suitability, (b) flow velocity suitability.

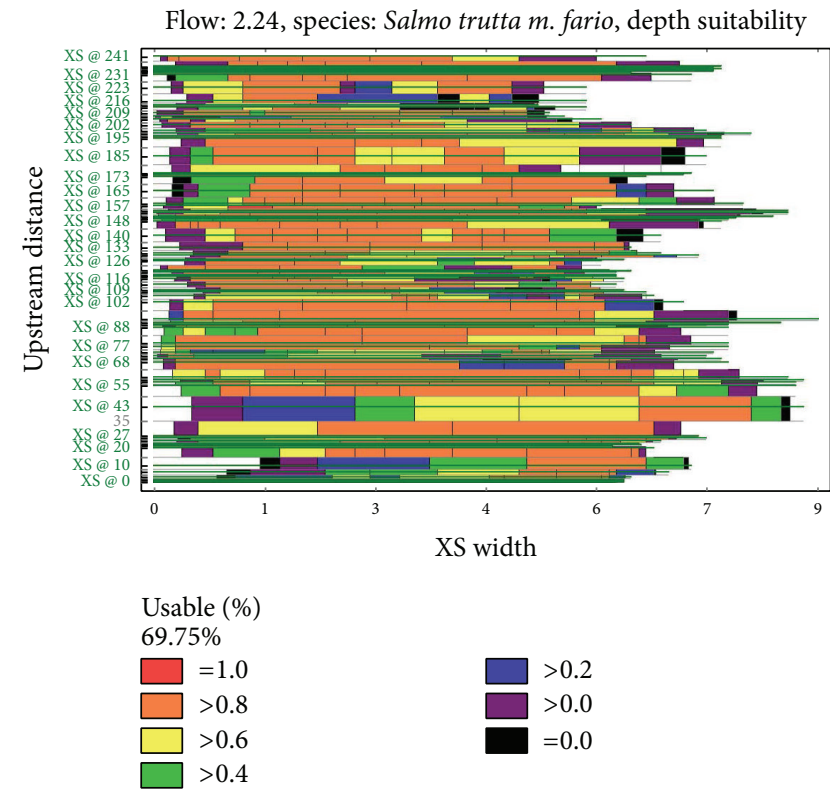

(a)

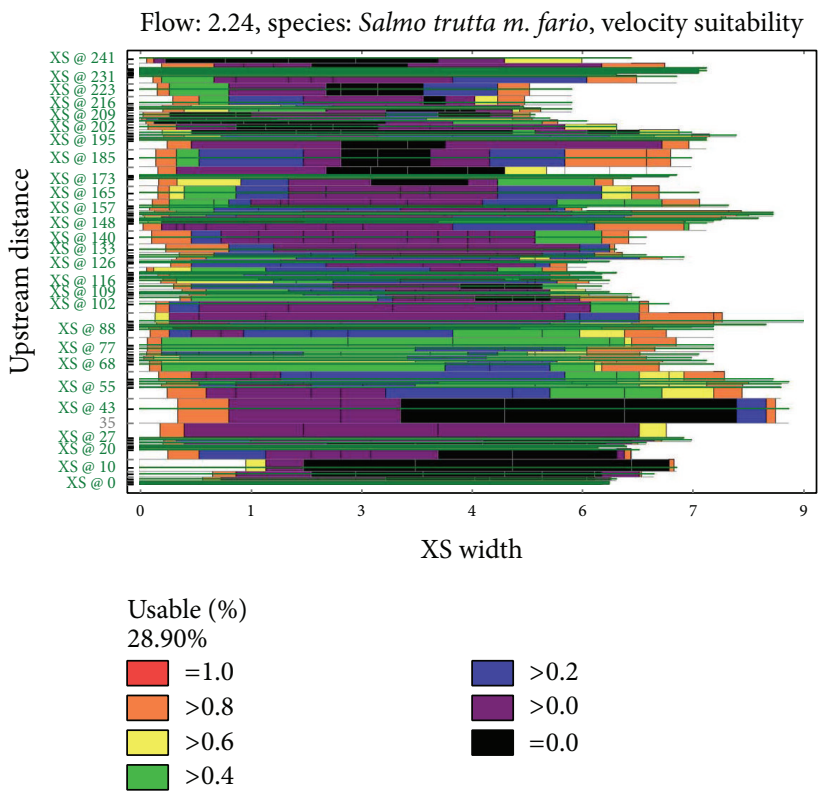

(b)

FIGURE 9: AWS during the discharge of $Q=2.235 \mathrm{~m}^{3} \cdot \mathrm{s}^{-1}$ using the HSCs evaluated during the discharge of $Q=0.085 \mathrm{~m}^{3} \cdot \mathrm{s}^{-1}$. (a) Water depth suitability, (b) flow velocity suitability.

was applied to the specific example of the Hybica River. The first stage of the simulation of the trend of minimum flows under the climate change scenario was executed as follows:

(i) Parameters of the rainfall-runoff model of the Hybica basin were calibrated based on the measured data of air temperature, precipitation, and discharges from the period of 01.11.1994-31.10.2002 using several rain gauging stations (Král'ova Lehota, Čierny Váh, Podbanské, and Hybe) and climate stations (Liptovský Hrádok, Podbanské).

(ii) Mean daily discharges for two future time periods (2021-2050 and 2071-2100) and the reference 

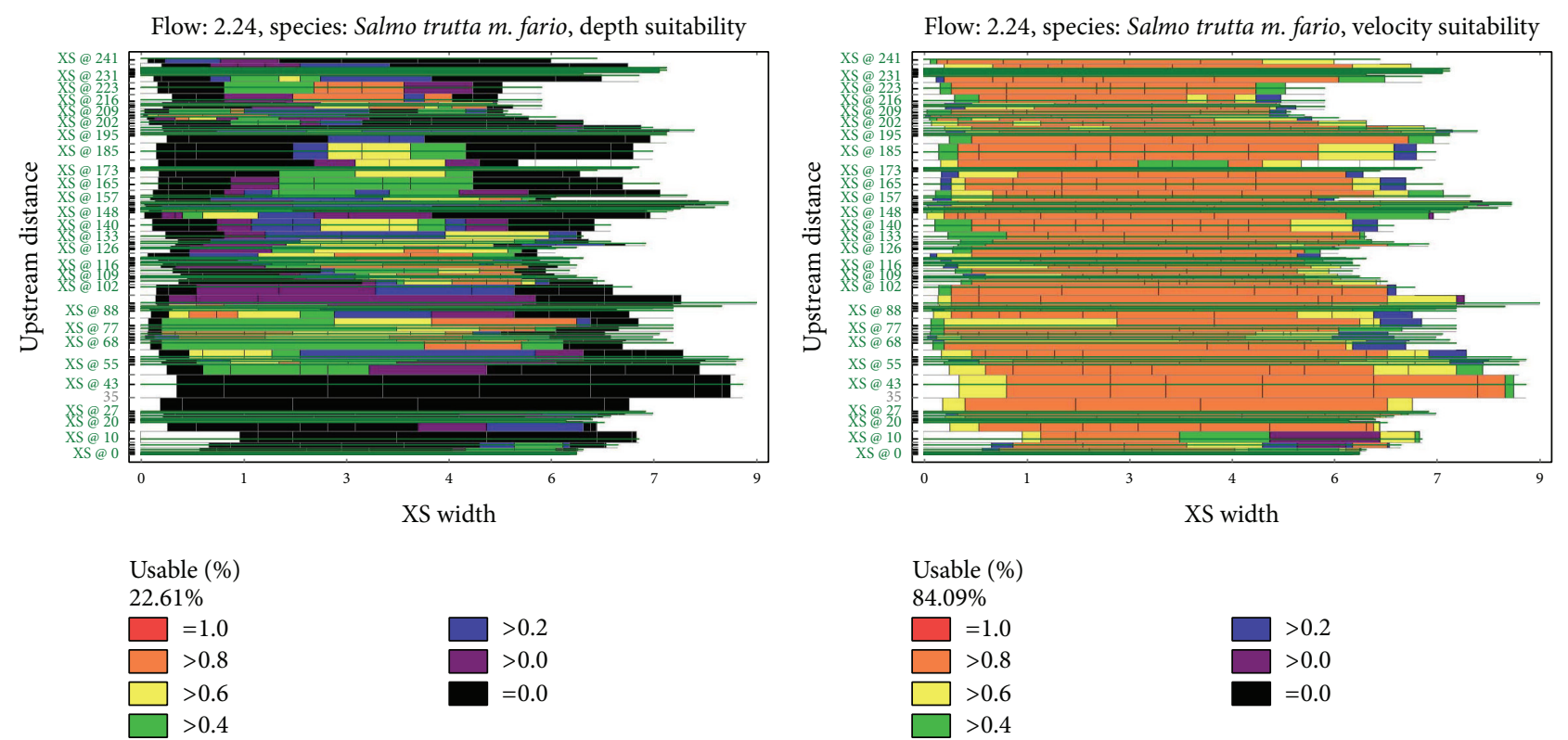

(a)

(b)

FIGURE 10: AWS during the discharge of $Q=2.235 \mathrm{~m}^{3} \cdot \mathrm{s}^{-1}$ using the HSCs evaluated during the discharge of $Q=1.48 \mathrm{~m}^{3} \cdot \mathrm{s}^{-1}$. (a) Water depth suitability, (b) flow velocity suitability.

period (1961-1990) for the Hybica River basin were simulated. The simulation results were statistically compared with the measured values of mean daily minimum flows in the calibration period. Based on the high correspondence between the simulated and measured minimum flows, the mean daily minimum flows for the future time periods were determined.

(iii) The impact of changes in the flow regime on the quality of the aquatic habitat at Hybica River as a result of climate change was investigated.

Hybica is a right tributary of the Váh River with a length of $18.7 \mathrm{~km}$ and a catchment area of $44.71 \mathrm{~km}^{2}$. The morphology of the riverbed is very rugged and produces a varied range of microhabitats. For the selected reach sudden changes in the curvature and vertical alignment of the bottom are characteristic. The average slope of the channel is $0.7 \%$. The shores are covered by deciduous trees and bushes that create shade in a significant part of the channel. The ichthyological and topographical research was carried out in the reference reach of the stream with a length of $113 \mathrm{~m}$. The species and quantitative composition of the ichthyofauna were as follows:

Brown trout (Salmo trutta m. fario), 42 pcs.

Carpathian sculpin (Cottus poecilopus), 19 pcs.

Grayling (Thymallus thymallus), 17 pcs.

4.1. Modelling of the Minimum Flows for the Hybica River Basin for Future Time Periods. For the modeling of the flows for the Hybica River basin, two different rainfall-runoff models were tested, the WetSpa distributed model and the
Hron conceptual model. Calibration of the model parameters was carried out on the basis of the measured data of the air temperature and precipitation at the different stations from 1.11.1994 to 31.10.2002. The calibration was focused on achieving the best correlation between the measured and simulated mean daily discharges during the summer period. The period from May until August was considered as the summer period. Based on the measured data it was determined that the most frequent occurrence of minimum flows and also the most demanding conditions for biota occur in August. For this reason, not only was the calibration coefficient of the Nash Sutcliffe (N-S) correlation important, but also, in particular, the graphic compliance of the measured and simulated mean daily discharges of this month was also important.

The Hron model achieved a higher degree of consistency between the measured and simulated mean daily discharges compared with the WetSpa model for the summer season observed. Therefore, for the evaluation of the impact of climate change on the quality of the in-stream habitat, the Hron rainfall-runoff model was used.

The N-S correlation coefficient did not achieve a globally high degree of conformity $(\mathrm{N}-\mathrm{S}=0.67)$, due to the fact that during the calibration, particular attention was paid to the graphic compliance of the minimum mean daily flows, and the maximum flows were ignored. The choice of model parameters was adapted to this kind of calibration. The results of the comparison of the measured and simulated flows showed that in the month of August, almost total agreement between the simulated and measured long-term mean monthly and daily discharges has been achieved (Figure 11(a)).

The compliance was not achieved just for the long-term mean monthly and daily values but also was reached for 


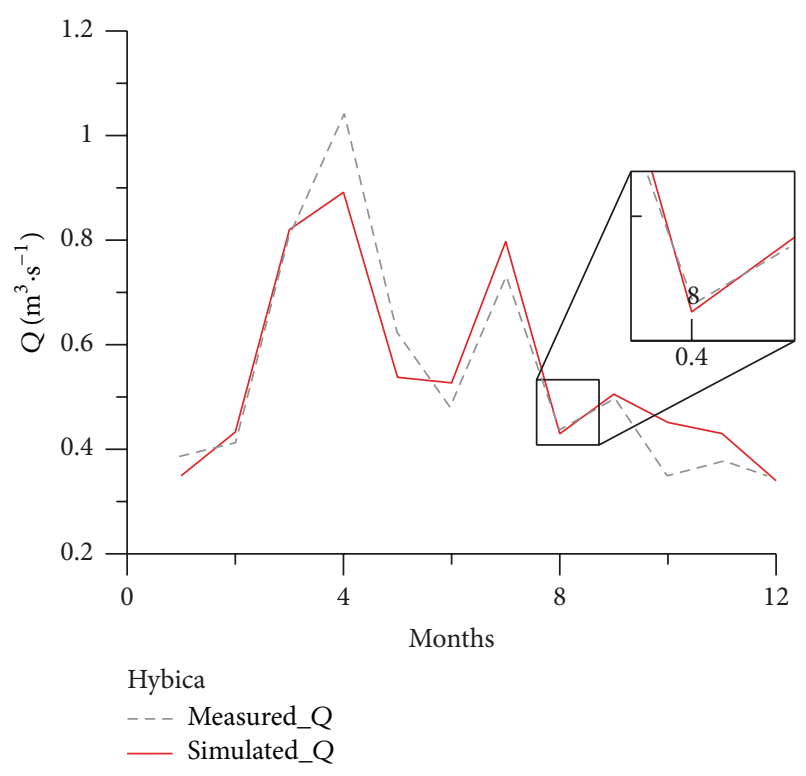

(a)

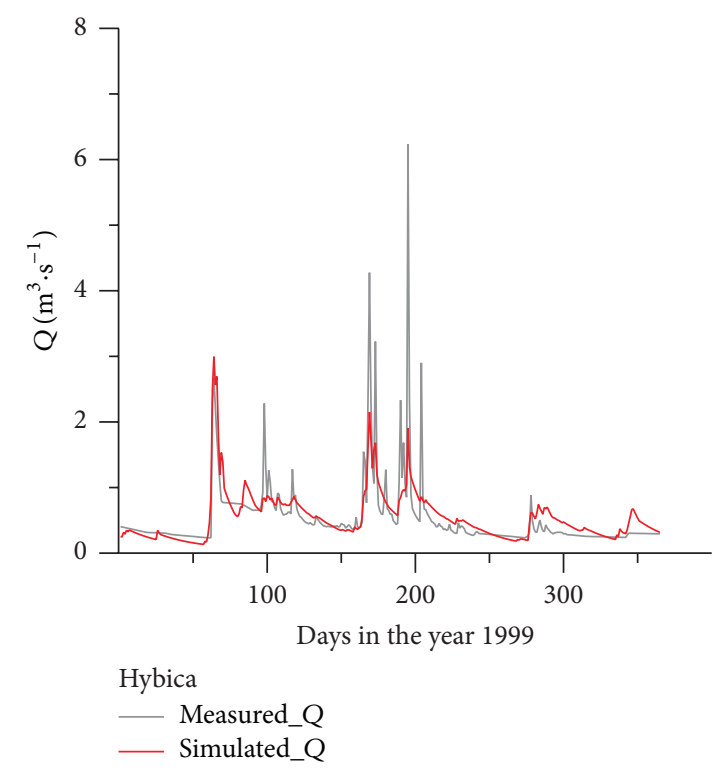

(b)

Figure 11: Results of the comparison by the Hron model as (a) the monthly average discharges in the closing profile of the Hybica basin and as (b) the mean daily discharges in the closing profile for the year 2000.

the concrete value of the mean daily minimum flow, which occurred in the measured and the simulated periods on the same day (27.8.1995). The measured mean daily minimum flow was equal to $0.156 \mathrm{~m}^{3} \cdot \mathrm{s}^{-1}$, and the simulated mean daily minimum flow was $0.151 \mathrm{~m}^{3} \cdot \mathrm{s}^{-1}$. Other summer months showed a similar consistency of long-term mean monthly and daily flows.

Based on the calibrated parameters of the models, the simulation was performed for the reference period 1961-1990 and the two future time periods of 2021-2050 and 2071-2100. For the choice of the most extreme climate change scenario, the simulation of the flow changes for the Váh River basin, where the Hybica River is located, was performed. Out of the three climate change scenarios (ALADIN-Climate, KNMI, and MPI), the ALADIN-Climate scenario was selected for assessing the impact of climate change on the quality of the in-stream habitat for the Hybica River. This scenario assumes the most extreme decrease in flows for the future periods compared to the KNMI and MPI scenarios (Figure 12).

Next, the minimum mean daily discharges of each 30 year period for the Hybica River were evaluated, because the minimum water levels are the most crucial for the aquatic biota. For the period 2021-2050, the minimum average daily discharge was $0.17 \mathrm{~m}^{3} \cdot \mathrm{s}^{-1}$, which occurred specifically on August 29, 2025, and for the period from 2071 to 2100, it was the flow equal to $0.06 \mathrm{~m}^{3} \cdot \mathrm{s}^{-1}$, which, based on the simulation, occurred on 22 August 2079. In the period 1961-1990, the lowest simulated mean daily flow was $0.22 \mathrm{~m}^{3} \cdot \mathrm{s}^{-1}$.

It can be concluded that according to the results the flows in the summer periods in the future will decrease. The results are documented on the map of the runoff changes by 2100 compared to the reference period 1961-1990. From this map it is clear that the flow will decrease, especially in the
TABLE 4: The $m$-day discharges in the reference reach of the Hybica River ( $m$ is the periodicity of achieving or exceeding the discharge).

\begin{tabular}{lccccccc}
\hline$m[$ day $]$ & 30 & 90 & 180 & 270 & 330 & 355 & 364 \\
\hline$Q_{m}\left[\mathrm{~m}^{3} \cdot \mathrm{s}^{-1}\right]$ & 2.319 & 0.952 & 0.471 & 0.24 & 0.139 & 0.083 & 0.037 \\
\hline
\end{tabular}

high mountain areas (Figure 13). Such results have been also documented in the newest studies such as [40-42] and many others.

4.2. Assessment of the Quality of the In-Stream Habitat of the Hybica River. The ichthyological survey of the selected reaches was oriented towards determination of the suitability curves for the individual fish species. The data were obtained by electrofishing similarly as in [43].

The topographical measurement of the individual reaches was adapted to the requirements of the hydraulic modeling. Cross sections were measured by leveling; at the characteristic profiles the water level was fixed to static points, which accelerated the measurement of the water level regimes at different flows.

The quality of the habitat was evaluated at different discharges. These were not chosen randomly, but the real values of the $m$-day discharges were used (Table 4). Determination of the $m$-day discharges was realized in cooperation with the Slovak Hydrometeorological Institute in Bratislava. The evaluation was in accordance with the STN 75 1410-1 national standard, where the method of interpolation between two gauging stations was used.

4.3. Impact of Changes in the Flow Regime, as a Result of Climate Change, on the Quality of the Biota of the Hybica River. The impact of climate change will mainly be reflected 


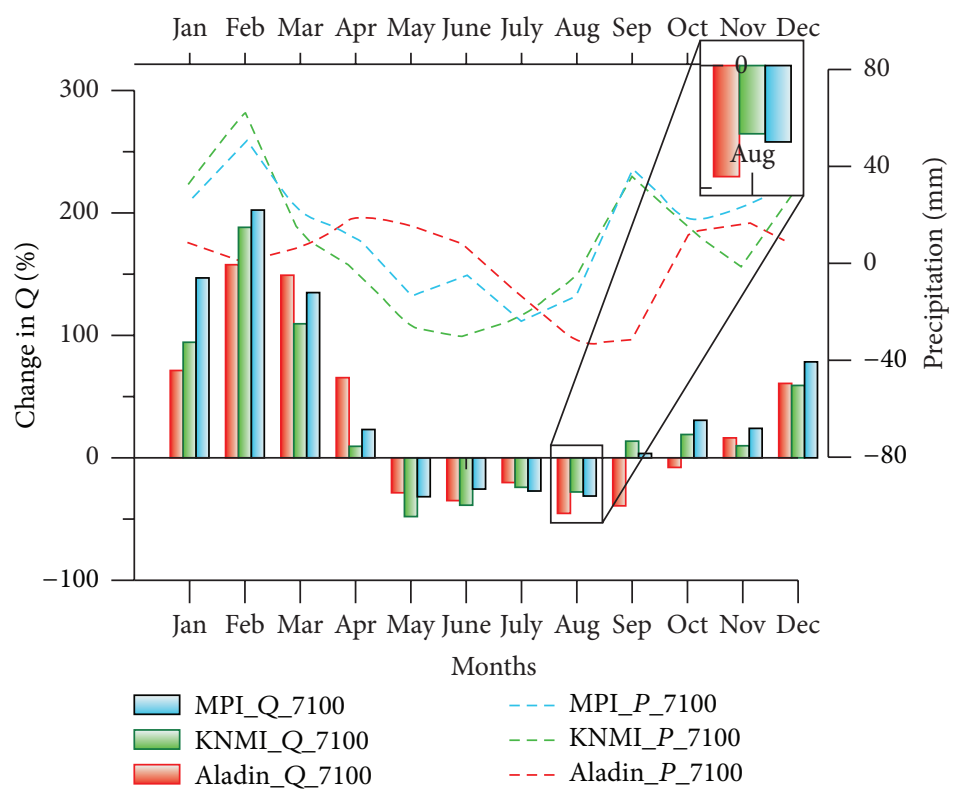

FIGURE 12: Evaluation of changes in precipitation and discharges in the closing profile of the Váh basin by the year 2100 as a change against the reference period 1961-1990 using the WetSpa hydrological model and individual scenarios.

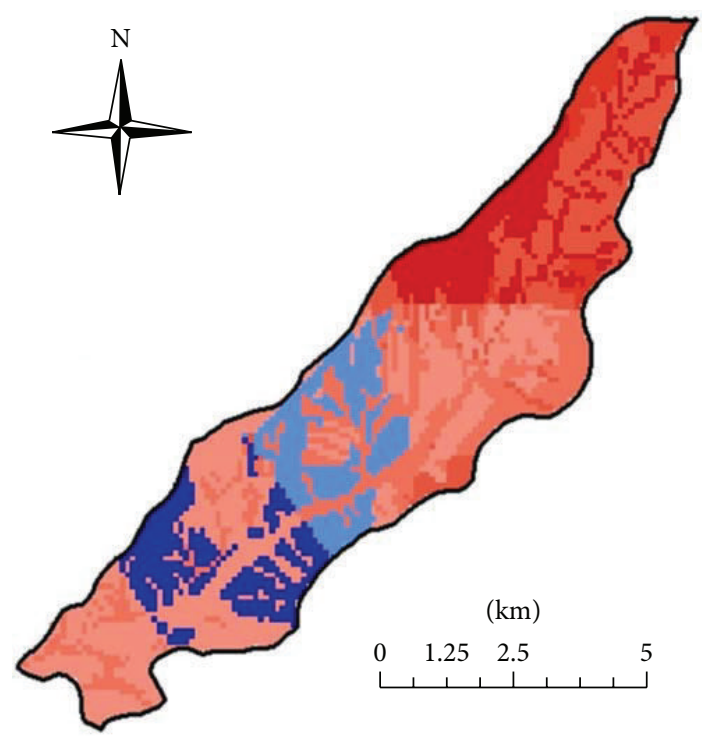

$\begin{array}{ll}\text { Change in } Q \text { (mm/year) } & \\ \begin{array}{ll}\square-100--80 & \\ \square-10-0 \\ -70--60 & \square \\ \square-50--40 & \square-10 \\ \square-30--20 & \end{array}\end{array}$

FIGURE 13: Changes in the mean annual surface runoff in the Hybica basin in the period 2071-2100 compared to the reference period 1961-1990.

in aquatic areas by changing of the flow, which has a direct impact on the abiotic characteristics of the channel. The biotic habitat parameters are represented by fish as bioindicators of the in-stream habitat quality. The relationship between the abiotic and biotic characteristics is represented by the suitability curves of the individual species. The most demanding area in the modeling of an aquatic habitat is the determination of the HSCs. These were derived from an ichthyological survey conducted by the Department of Land and Water Resources Management, Slovak University of Technology in Bratislava, in cooperation with the Slovak Agricultural University in Nitra directly at the reference reaches of the Hybica River. The topographical characteristics were determined by leveling and water-level regime has been verified on the basis of the hydrometry and measurements of the water levels at each cross section. This is a set of data which allows us to model the quality of the habitat in the RHABSIM model.

Figure 14 shows a gradual change in the quality of the aquatic habitat according to the modified discharge. The change in the quality of the aquatic habitat was simulated for the discharges that have been assessed as the minimum daily flows for each evaluated 30-year period.

During minimum flows, the quality of microhabitats where the biota is focused is important. The remaining part of the channel does not have a significant impact on the conservation of the in-stream biota. In other words, it is important that the stream provides a satisfactory habitat (level of suitability of more than 0.4 ).

Figures 14(b) and 14(c) show that the quality of the aquatic habitat for the two future periods modeled decreases with a decreasing mean daily minimum discharge compared to the reference period (discharge of $0.22 \mathrm{~m}^{3} \cdot \mathrm{s}^{-1}$, which occurred at the time of the ichthyological measurements). At a discharge of $0.17 \mathrm{~m}^{3} \cdot \mathrm{s}^{-1}\left(Q_{330}\right)$, the quality of the habitat where the biota is concentrated did not change significantly. At the discharge of $0.06 \mathrm{~m}^{3} \cdot \mathrm{s}^{-1}\left(Q_{355}\right)$ a significant change occurred. A suitable habitat was reduced to only one cell. This means that this 


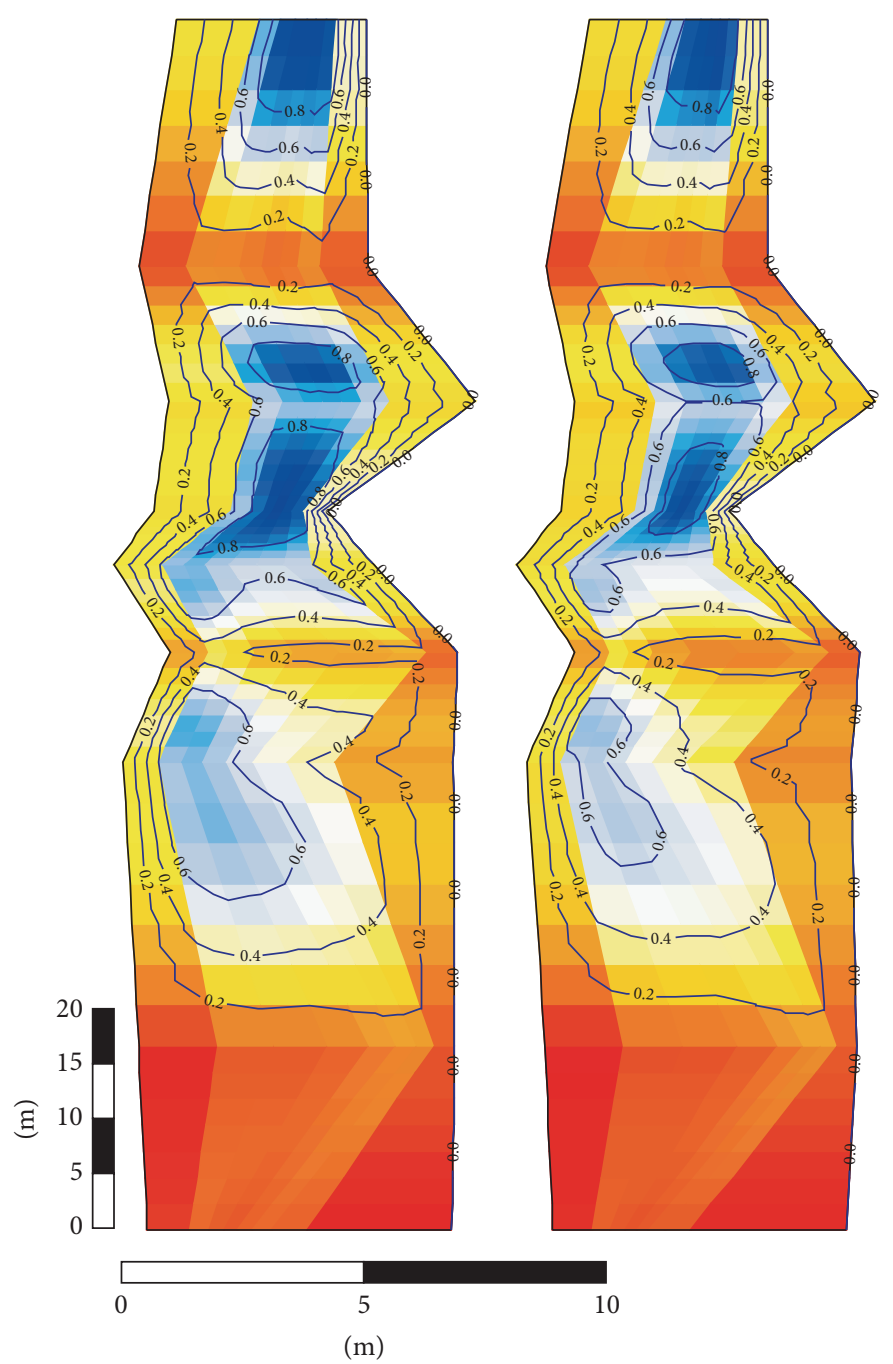

(a) (b)

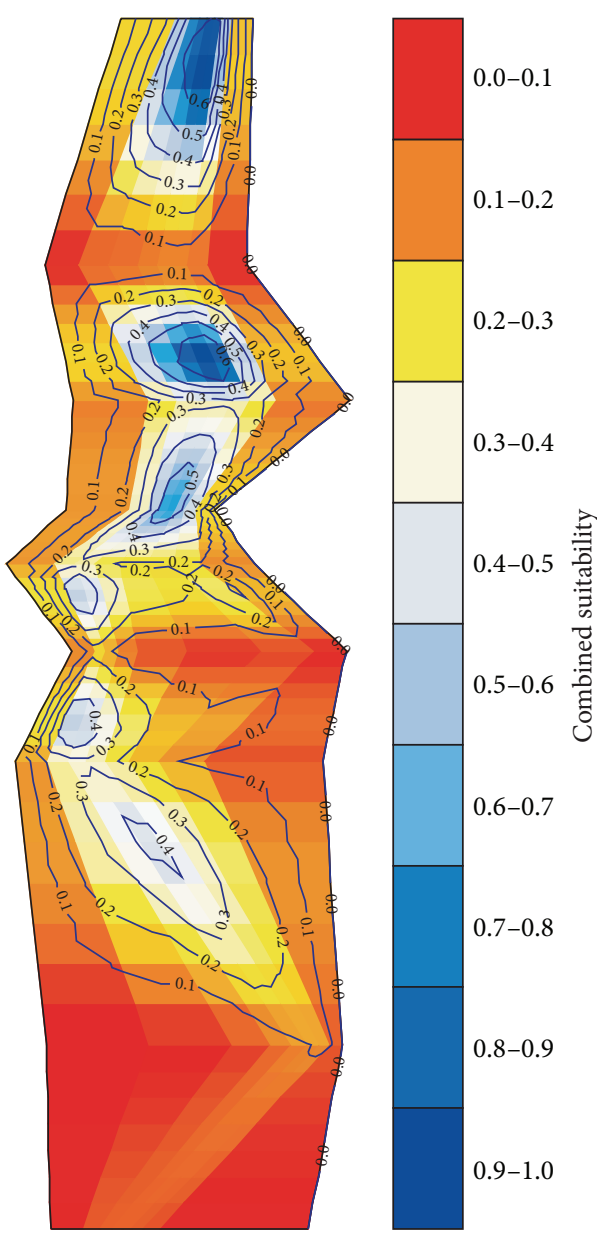

(c)

FIGURE 14: Evaluation of the quality of the in-stream habitat by the RHABSIM model in the Hybica River for the discharge of (a) $Q=$ $0.22 \mathrm{~m}^{3} \cdot \mathrm{s}^{-1}$ (1961-1990), (b) $Q=0.17 \mathrm{~m}^{3} \cdot \mathrm{s}^{-1}(2021-2050)$, and (c) $Q=0.06 \mathrm{~m}^{3} \cdot \mathrm{s}^{-1}(2071-2100)$.

discharge would have a significant impact not only on the reduction of the in-stream habitat, but also on the biodiversity in this reach. On the basis of these results we can conclude that according to the ALADIN-Climate scenario we could expect significant changes in the quality of the aquatic habitat for the future time period of 2071-2100.

\section{Conclusions}

Analysis of the relationship between the shape of the HSCs and the abiotic parameters of the in-stream habitat showed that the shapes of the curves are strongly related to the relevant parameters, in particular to the water depth and flow velocity. These two characteristics define the shape of the HSCs, which represent a wider range of discharges. Further analysis was aimed at evaluating the AWS in terms of the impact of the water depth and flow velocity. The results show that the water depth has a significantly greater effect on the quality of the in-stream habitat than the flow velocity and that the optimum ratio between these parameters is as follows: $W_{D}: W_{V}=8: 2$.

There is little information about the modeling of the quality of an in-stream habitat in terms of the trends in climate change. The described methodology enhances the ability to obtain such information. The results show that climate change may cause significant modifications in the ecosystem of watercourses. Based on these results it is possible to design and evaluate restorative measures that could mitigate the impact of climate change on the in-stream areas of watercourses.

\section{Conflict of Interests}

The authors declare that there is no conflict of interests regarding the publication of this paper. 


\section{Acknowledgments}

This study has been jointly supported by the Slovak Research and Development Agency under Contract no. APVV-030311 and by the Scientific Grant Agency under Contracts no. VEGA 1/0625/15 and VEGA 1/0665/15.

\section{References}

[1] N. Friberg, A. Baattrup-Pedersen, M. L. Pedersen, and J. Skriver, "The new Danish stream monitoring programme (NOVANA)-preparing monitoring activities for the Water Framework Directive era," Environmental Monitoring and Assessment, vol. 111, no. 1-3, pp. 27-42, 2005.

[2] I. G. Jowett, "Instream flow methods: a comparison of approaches," Regulated Rivers: Research \& Management, vol. 13, no. 2, pp. 115-127, 1997.

[3] T. B. Hardy, "The future of habitat modeling and instream flow assessment techniques," Regulated Rivers: Research \& Management, vol. 14, no. 5, pp. 405-420, 1998.

[4] R. E. Tharme, "A global perspective on environmental flow assessment: emerging trends in the development and application of environmental flow methodologies for rivers," River Research and Applications, vol. 19, no. 5-6, pp. 397-441, 2003.

[5] S. Mérigoux, N. Lamouroux, J.-M. Olivier, and S. Dolédec, "Invertebrate hydraulic preferences and predicted impacts of changes in discharge in a large river," Freshwater Biology, vol. 54, no. 6, pp. 1343-1356, 2009.

[6] I. D. Hodkinson and J. K. Jackson, "Terrestrial and aquatic invertebrates as bioindicators for environmental monitoring, with particular reference to mountain ecosystems," Environmental Management, vol. 35, no. 5, pp. 649-666, 2005.

[7] O. Slavík, L. Bartoš, and D. Mattas, "Does stream morphology predict the home range size in burbot?" Environmental Biology of Fishes, vol. 74, no. 1, pp. 89-98, 2005.

[8] N. Lamouroux, J.-M. Olivier, H. Capra, M. Zylberblat, A. Chandesris, and P. Roger, "Fish community changes after minimum flow increase: testing quantitative predictions in the Rhône River at Pierre-Bénite, France," Freshwater Biology, vol. 51, no. 9, pp. 1730-1743, 2006.

[9] V. Macura, A. Škrinár, K. Kaluz, M. Jalčovíková, and M. Škrovinová, "Influence of the morphological and hydraulic characteristics of mountain streams on fish habitat suitability curves," River Research and Applications, vol. 28, no. 8, pp. 11611178, 2012.

[10] J. A. Thomas and K. D. Bovee, "Application and testing of a procedure to evaluate transferability of habitat suitability criteria," Regulated Rivers: Research \& Management, vol. 8, no. 3, pp. 285-294, 1993.

[11] C. B. Stalnaker, B. L. Lamb, J. Henriksen, K. Bovee, and J. Bartholow, "The instream flow incremental methodology: a primer for IFIM," Biological Report 29, National Biological Service, 1995.

[12] C.-Y. Xu, "Modelling the effects of climate change on water resources in central Sweden," Water Resources Management, vol. 14, no. 3, pp. 177-189, 2000.

[13] O. B. Haddad, M. Jahandideh-Tehrani, and M. A. Mariño, "Discussion of 'investigating the vulnerability of dry-season water supplies to climate change: a case study of the Gwangdong reservoir drought management system, Korea' by Donghoon Cha; Sangeun Lee; and Heekyung Park," Water Resources Management, vol. 27, no. 7, pp. 1893-1896, 2013.
[14] F. Fung, G. Watts, A. Lopez, H. G. Orr, M. New, and C. Extence, "Using large climate ensembles to plan for the hydrological impact of climate change in the freshwater environment," Water Resources Management, vol. 27, no. 4, pp. 1063-1084, 2013.

[15] I. Maddock, "The importance of physical habitat assessment for evaluating river health," Freshwater Biology, vol. 41, no. 2, pp. 373-391, 1999.

[16] D. Ayllón, A. Almodóvar, G. G. Nicola, and B. Elvira, "Interactive effects of cover and hydraulics on brown trout habitat selection patterns," River Research and Applications, vol. 25, no. 8, pp. 1051-1065, 2009.

[17] D. Ayllón, A. Almodóvar, G. Nicola, and B. Elvira, "Modelling brown trout spatial requirements through physical habitat simulations," River Research and Applications, vol. 26, no. 9, pp. 1090-1102, 2010.

[18] D. Ayllón, A. Almodóvar, G. G. Nicola, and B. Elvira, "The influence of variable habitat suitability criteria on PHABSIM habitat index results," River Research and Applications, vol. 28, no. 8, pp. 1179-1188, 2012.

[19] K. D. Bovee, "Use of the instream flow incremental methodology to evaluate the influence of microhabitat variability on trout populations in four Colorado streams," in Proceedings of the Western Division of the American Fisheries Society, pp. 227257, Albuquerque, NM, USA, 1988.

[20] A. L. Conder and T. C. Annear, "test of weighted usable area estimates derived from a PHABSIM model for instream flow studies on trout streams," North American Journal of Fisheries Management, vol. 7, no. 3, pp. 339-350, 1987.

[21] I. G. Jowett, "Models of the abundance of large brown trout in New Zealand rivers," North American Journal Fisheries Management, vol. 12, pp. 417-432, 1992.

[22] R. B. Nehring and R. M. Anderson, "Determination of population-limiting critical salmonid habitats in Colorado streams using the Physical Habitat Simulation system," Rivers, vol. 4, no. 1, pp. 1-19, 1993.

[23] S. P. Gallagher and M. F. Gard, "Relationship between chinook salmon (Oncorhynchus tshawytscha) redd densities and PHABSIM-predicted habitat in the Merced and Lower American rivers, California," Canadian Journal of Fisheries and Aquatic Sciences, vol. 56, no. 4, pp. 570-577, 1999.

[24] D. Mathur, W. H. Bason, E. J. Purdy Jr., and C. A. Silver, "A critique of the in stream flow incremental methodology," Canadian Journal of Fisheries and Aquatic Sciences, vol. 42, no. 4, pp. 825-831, 1985.

[25] D. Mathur, W. H. Bason, E. J. Purdy Jr., and C. A. Silver, "Reply to "in defense of the instream flow incremental methodology", Canadian Journal of Fisheries and Aquatic Sciences, vol. 43, no. 5, pp. 1084-1094, 1986.

[26] J. L. Meyer, M. J. Sale, P. J. Mulholland, and N. L. Poff, "Impacts of climate change on aquatic ecosystem functioning and health," Journal of the American Water Resources Association, vol. 35, no. 6, pp. 1373-1386, 1999.

[27] D. Scott and C. S. Shirvell, "A critique of the instream flow incremental methodology and observations on flow determination in New Zealand," in Regulated Streams, J. Craig and J. B. Kemper, Eds., pp. 27-43, Springer, New York, NY, USA, 1987.

[28] C. S. Shirvell, "Ability of PHABSIM to predict chinook salmon spawning habitat," Regulated Rivers: Research \& Management, vol. 3, no. 1, pp. 277-289, 1989.

[29] J. Cohen, Statistical Power Analysis for the Behavioral Sciences, Lawrence Earlbaum Associates, Hillsdale, NJ, USA, 2nd edition, 1988. 
[30] K. V. Grišanin, Dinamika ruslovych potokov, Gidrometeoizdat, Leningrad, Russia, 1981.

[31] T. H. Oliver and M. D. Morecroft, "Interactions between climate change and land use change on biodiversity: attribution problems, risks, and opportunities," Wiley Interdisciplinary Reviews: Climate Change, vol. 5, no. 3, pp. 317-335, 2014.

[32] G. E. Petts, "Instream flow science for sustainable river management," Journal of the American Water Resources Association, vol. 45, no. 5, pp. 1071-1086, 2009.

[33] Z. Li, X. Deng, J. Huang, R. Zhang, and J. Huang, "Critical studies on integrating land-use induced effects on climate regulation services into impact assessment for human wellbeing," Advances in Meteorology, vol. 2013, Article ID 831250, 14 pages, 2013.

[34] T. Beechie, H. Imaki, J. Greene et al., "Restoring salmon habitat for a changing climate," River Research and Applications, vol. 29, no. 8, pp. 939-960, 2013.

[35] C. T. Graham and C. Harrod, "Implications of climate change for the fishes of the British Isles," Journal of Fish Biology, vol. 74, no. 6, pp. 1143-1205, 2009.

[36] P. Valent, J. Szolgay, and C. Riverso, "Split sample calibration of the HBV model using artificially generated flows," in Proceedings of the HydroCarpath, Catchment Processes in Regional Hydrology: From Experiment to Modeling in Carpathian Drainage Basins, p. 5, University of West Hungary, Sopron, Hungary, October 2012.

[37] Z.-M. Wang, O. Batelaan, and F. De Smedt, "A distributed model for water and energy transfer between soil, plants and atmosphere (WetSpa)," Physics and Chemistry of the Earth, vol. 21, no. 3, pp. 189-193, 1996.

[38] P. Skalák, P. Štěpánek, and A. Farda, "Validation of ALADINClimate/CZ for present climate (1961-1990) over the Czech Republic," Időjárás, vol. 122, no. 3-4, pp. 191-201, 2008.

[39] Z. Štefunková, K. Hlavčová, and M. Lapin, "Runoff change scenarios based on regional climate change projections in mountainous basins in Slovakia," Contributions to Geophysics and Geodesy, vol. 43, no. 4, pp. 327-350, 2013.

[40] C. Schneider, C. L. R. Laizé, M. C. Acreman, and M. Flörke, "How will climate change modify river flow regimes in Europe?" Hydrology and Earth System Sciences, vol. 17, no. 1, pp. 325-339, 2013.

[41] W. J. Fisk, "Review of some effects of climate change on indoor environmental quality and health and associated no-regrets mitigation measures," Building and Environment, vol. 86, pp. 70-80, 2015.

[42] M. Höglind, S. M. Thorsen, and M. A. Semenov, "Assessing uncertainties in impact of climate change on grass production in Northern Europe using ensembles of global climate models," Agricultural and Forest Meteorology, vol. 170, pp. 103-113, 2013.

[43] N. Lamouroux, H. Capra, M. Pouilly, and Y. Souchon, "Fish habitat preferences in large streams of southern France," Freshwater Biology, vol. 42, no. 4, pp. 673-687, 1999. 

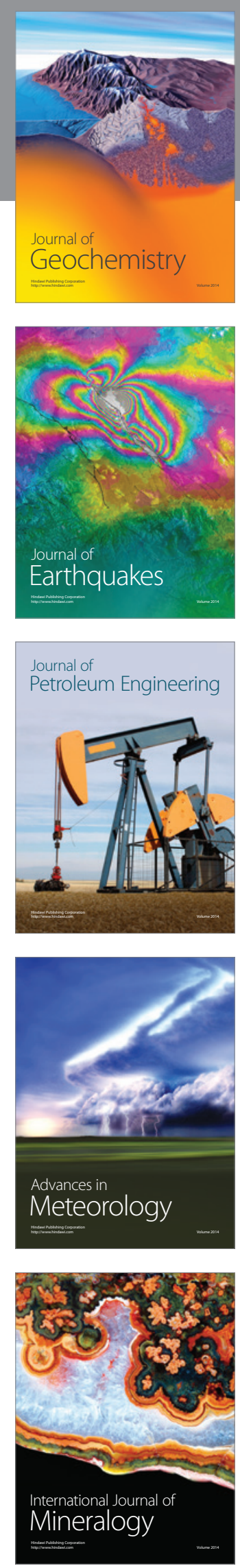
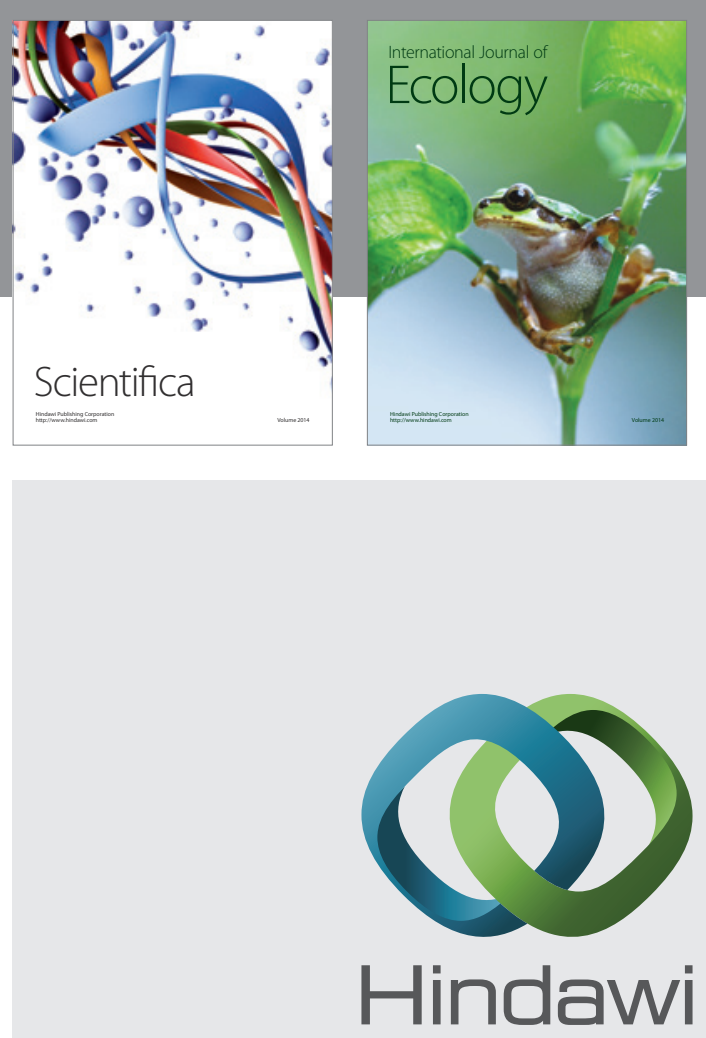

Submit your manuscripts at

http://www.hindawi.com
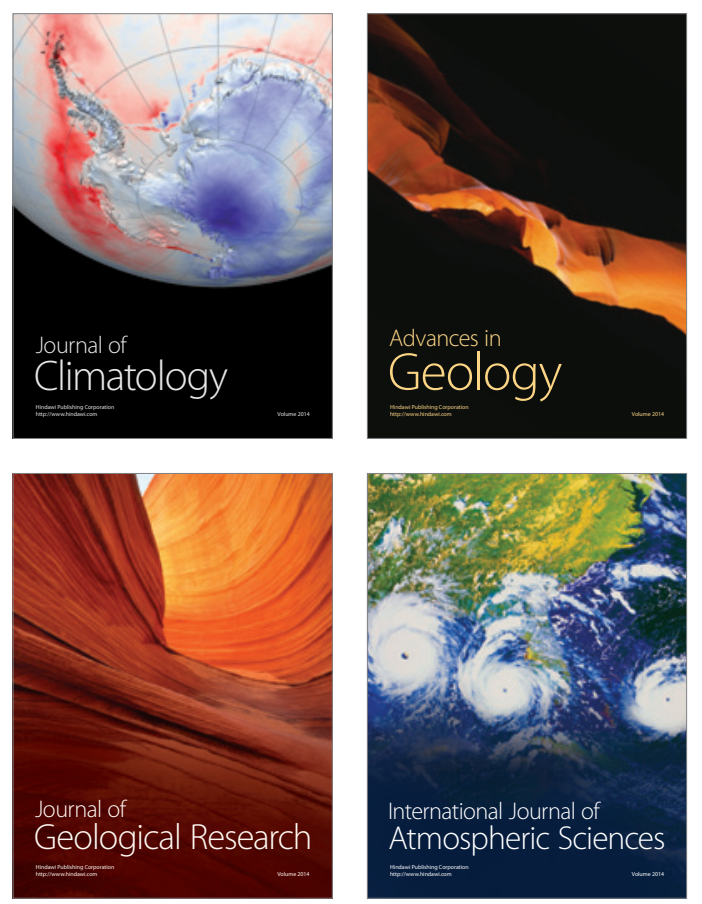

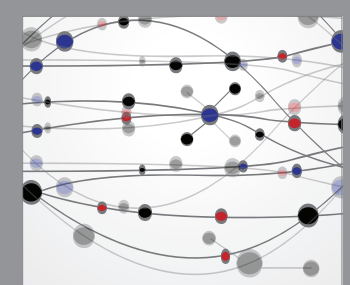

The Scientific

\section{World Journal}
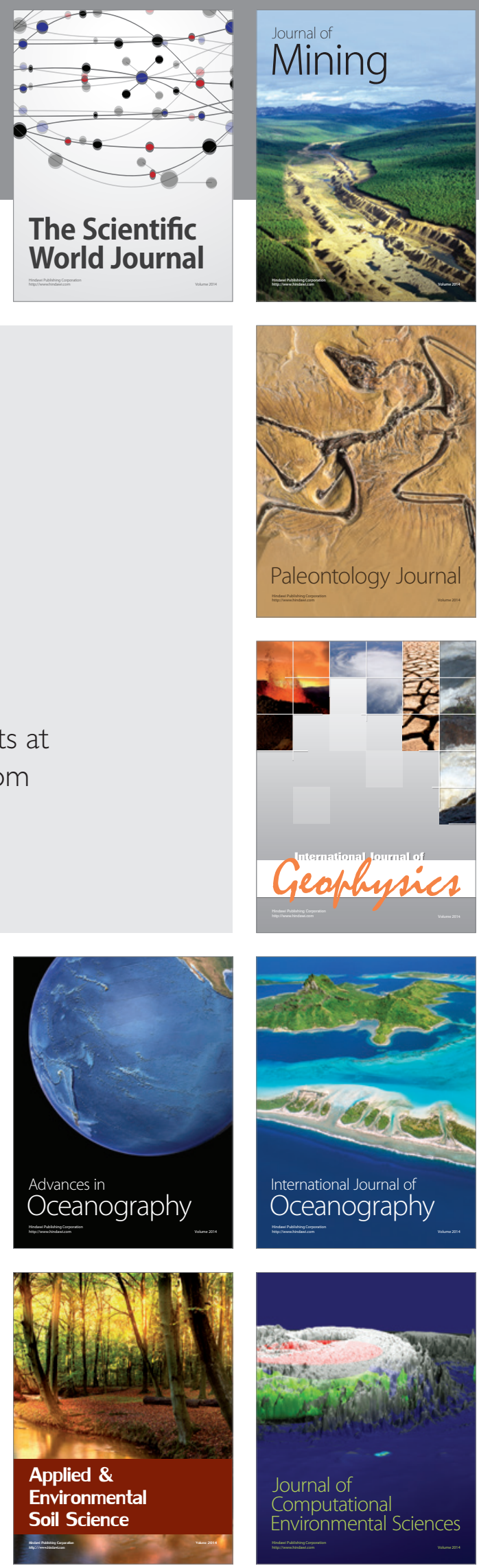